This is the accepted manuscript of the article, which has been published in Journal of Applied Psychology https://doi.org/10.1037/apl0000495

\title{
An Identity-based Integrative Needs Model of Crafting: \\ Crafting within and across life domains
}

\author{
J. de Bloom ${ }^{1,2}$, H. Vaziri ${ }^{3}$, L. Tay ${ }^{4}$, M. Kujanpää ${ }^{1}$
}

Please refer to this paper as:

De Bloom, J., Vaziri, H., Tay, L., \& Kujanpää, M. (in press). An identity-based integrative needs model of crafting: Crafting within and across life domains. Journal of Applied Psychology

CAmerican Psychological Association, 2020. This paper is not the copy of record and may not exactly replicate the authoritative document published in the APA journal. Please do not copy or cite without author's permission.

This study was supported by an Academy of Finland Researcher grant received by the first author (decision number: 308718).

\footnotetext{
${ }^{1}$ Tampere University, Tampere, Finland, Address: FI-33014 University of Tampere (Finland) ${ }^{2}$ University of Groningen, Groningen, Netherlands, Address: Faculty of Economics \& Business, Nettelbosje 2, 9747 AE Groningen, Netherlands

${ }^{3}$ University of North Texas, Department of Management' 1155 Union Circle \#305429, Denton, Texas 76203-5017 USA

${ }^{4}$ Purdue University, West-Lafayette, USA, Department of Psychological Sciences, Purdue University, 703 Third Street, West Lafayette, IN 47907-2081 USA
} 


\title{
An Identity-based Integrative Needs Model of Crafting: Crafting within and across life domains
}

\begin{abstract}
In recent years, there has been heightened interest in the active role of employees in shaping activities and experiences in their pursuit of optimal functioning (i.e., feeling and performing well), referred to as job-, leisure-, home-, and work-life balance crafting. Various perspectives have emphasized distinct dimensions within the crafting process (i.e., motives, behaviors, life domains, and outcomes) yielding a rich but fragmented theoretical account. With psychological needs satisfaction as the underlying process, we propose an integrative model to account for past conceptualizations of crafting motives and efforts across a person's various role identities. This integration highlights the importance of recognizing unfulfilled needs, matching needs and crafting efforts, within- and between-level temporal dynamics of the crafting process, and possibilities for spillover and compensation processes across identity domains. Accordingly, the Integrative Needs Model of Crafting explains a) why and how people craft, b) when and why crafting efforts may (not) be effective in achieving optimal functioning, c) the sequential process of crafting over time, and d) how crafting processes unfold across different identity domains.
\end{abstract}

Keywords: psychological needs, off-job crafting, leisure crafting, job crafting, identity 


\section{Introduction}

Technological advances, organizational, economic, and societal changes like flattening organizational structures, freelance work, and emphasis on work agility and flexibility afford employees greater opportunities for independence and autonomy at work. Nowadays, employees are increasingly considered to be "[...] proactive organisms that have the inclination to shape and optimize their own life conditions" (Vansteenkiste \& Ryan, 2013; p. 264) and not passive respondents to situational or domain-specific forces. Employees proactively shape their situations and seek improvements aligned with their personal goals (Gravador \& Teng-Calleja, 2018; Sheldon \& Elliot, 1999). Even within the typical job boundaries, employees may modify their thoughts, tasks, and relational ties to cultivate meaningful jobs and a positive work identity (Wrzesniewski \& Dutton, 2001). Apart from employees' personal desire to adapt their jobs, organizations demand more self-management and personal initiative. Given the complexity of modern jobs, top-down job (re-)design is increasingly difficult and organizations prefer a bottom-up individual job (re-)design encouraging employees to develop and direct their work activities (e.g., Grant \& Parker, 2009; Lord, Diefendorff, Schmidt, \& Hall, 2010; Parker, Morgeson, \& Johns, 2017).

These trends towards self-management of job tasks and behaviors and experiences at work constitute job crafting, since the early 2000s as an important area of inquiry (Oldham \& Fried, 2016). Various theoretical models have subsequently been proposed and empirical studies abound, resulting in a rich fabric of research. Simultaneously, these distinct perspectives of job crafting often employ different definitions, measures, and emphases to explain why and how crafting occurs, resulting in a fragmented theoretical tapestry. While recent theoretical work has attempted to reconcile such inconsistencies across theoretical frameworks (e.g., Bruning \& Campion, 2018; Zhang \& Parker, 2018), past theorizing on crafting has focused on the work domain as a discrete entity. However, an employee's work 
domain entails numerous roles and identities (e.g., manager, subordinate, employee) that may be differently crafted. An integrative approach to job crafting is needed to fully understand crafting motives, behaviors, and outcomes within the work domain.

Crafting research has hitherto focused primarily on people's working lives while organizational research now seeks to understand the work experience holistically. Employees have many non-work roles and identities apart from their work roles. Actions and experiences in their non-work roles can significantly affect people's experiences at work and vice versa (e.g., Hecht \& Boies, 2009; Sonnentag, Venz, \& Casper, 2017). An integrative approach to understanding crafting, therefore, requires the incorporation of multiple identities across both work and non-work domains.

Apart from considering both work and non-work identities in research on work, we deem the development of disconnected crafting research and theorizing on crafting problematic for three main reasons. First, the differential and mostly implicit emphases on the motivation for crafting behaviors across different job crafting perspectives (i.e., person-job misfit versus building meaning and work identity) requires further elucidation. Second, research on non-work crafting is not well-connected to job crafting research. This is problematic because such a disconnect prevents researchers from identifying common underlying ideas, crafting themes, patterns, motives, behaviors, and outcomes. Moreover, as we later elaborate, work and non-work domains are not isolated; both domains influence and interact with the other.

Third, not only do we need to understand the common psychological processes underlying crafting in work and non-work domains but also to directly explicate the interplay between them; that is, crafting at the interface of work and non-work identities and their interactions through spillover, compensation, and conflict mechanisms (Edwards \& Rothbard, 2000; Hewett et al., 2017; Petrou \& Bakker, 2016). This integration will yield greater 
conceptual clarity and also direct practical considerations of how and when crafting may occur in the everyday lives of workers juggling different roles. In the following, we present an overview of empirical studies on crafting. Due to the plethora of job crafting research, reviews, and meta-analyses (e.g., Bindl, Unsworth, Gibson, \& Stride, 2018; Lichtenthaler \& Fischbach, 2018; Lazazzara, Tims, \& de Gennaro, 2019; Rudolph, Katz, Lavigne, \& Zacher, 2017; Zhang \& Parker, 2018), we focus on integrating crafting outside the work context and on the less researched interface between work and non-work life.

We draw on a common foundation of psychological needs and identity literature 1) to integrate different crafting perspectives, and 2) to extend crafting models across work and non-work identities. We define crafting as a motivated process including the goal-directed initiation of and engagement in crafting efforts intended to satisfy psychological needs. This definition distinguishes it from earlier behavioral definitions of crafting (e.g., Tims, Bakker, \& Derks, 2012), not including people's motivation for crafting behaviors.

Our proposed Integrative Needs Model of Crafting makes five contributions to the literature. First, we develop a process model of crafting applicable to individuals' role identities. The identity literature has long recognized that an individual's self-concept is a complex phenomenon comprising multiple identities across various life domains (Ramarajan, 2014), stemming from membership of social groups (e.g., organizational and gender identities), roles performed (e.g., manager, volunteer), relationships (e.g., relational identity with spouse and supervisor), and personal characteristics. These identities provide individuals with norms, beliefs, and behavioral expectations, and shape their behavior in certain situations (e.g., Blader \& Tyler, 2009; Conroy, Becker, \& Menges, 2017; Riketta, 2005; Sluss, Ployhart, Cobb \& Ashforth, 2012). Focusing primarily on role identities, we posit that individuals can craft within an identity domain to satisfy individual needs. Thus, we can incorporate a multitude of non-work identities into the crafting process and differentiate 
between numerous work-related identities. Elaborating on the interplay between identity domains, particularly across work and non-work, is timely, because work and non-work life are increasingly inseparable, and their reciprocal impact and interactions need to be considered within the crafting process. Our model posits that crafting processes across identity domains are interdependent. Relying on work-family research and boundary management literature (i.e., Allen, Cho, \& Meier, 2014; Edwards \& Rothbard, 2000; Kossek, Ruderman, Braddy, \& Hannum, 2012), we delineate compensation, spillover, and conflict mechanisms of crafting across identity domains.

Second, drawing on the Two-Process Model of Needs (Sheldon, 2011), we distinguish between needs discrepancy and needs satisfaction ${ }^{1}$ to reconcile inconsistencies regarding the conceptualization of psychological needs either as the motives or outcomes of crafting. Job crafting research has treated psychological needs as ultimate outcomes of crafting behaviors (e.g., Petrou \& Bakker, 2016) or as mediators between crafting behaviors and positive work outcomes (e.g., Van Wingerden, Bakker, \& Derks, 2017). However, psychological needs have also been treated as drivers of crafting behaviors (e.g., Bindl et al., 2018; Wrzesniewski \& Dutton, 2001). Distinguishing between needs discrepancy and needs satisfaction using the Two-Process Model of Needs addresses this inconsistency and provides conceptual clarity for delineating and operationalizing crafting processes. Needs discrepancy lies at the inception of a crafting episode (i.e., before crafting efforts are initiated), whereas needs satisfaction as experiential reward lies at the conclusion (phase) of a successful crafting episode (i.e., after crafting efforts). We propose that differences in psychological needs (i.e., needs discrepancy) partly explain individual differences in crafting motives while successful crafting efforts universally enhance the satisfaction of psychological needs (i.e., needs satisfaction).

\footnotetext{
${ }^{1}$ Sheldon (2011) calls these respectively needs-as-motives and needs-as-requirements.
} 
Third, our model integrates the two major crafting frameworks (Tims \& Bakker, 2010; Wrzesniewski \& Dutton, 2001) to address "how people craft", following Zhang and Parker (2018). Accordingly, we distinguish avoidance (i.e., precipitated by the desire to avoid negative outcomes/need frustration) and approach needs (i.e., aimed at pursuing a positive state/needs satisfaction) as crafting motives. We categorize actual crafting efforts into avoidance-focused (i.e., contraction-oriented crafting aimed at avoiding or reducing the negative aspects of work or non-work roles) and approach-focused (i.e., expansion-oriented crafting efforts aimed at approaching or adding desirable aspects of work or non-work identities; see also Bindl et al., 2018; Lichtenthaler \& Fischbach, 2018).

Fourth, we propose a matching perspective between crafting motives and actual crafting efforts in effective crafting. That is, avoidance needs (e.g., need for relaxation, optimal level of mental stimulation/stress, safety) are more likely to be accompanied by avoidance-focused crafting (e.g., reducing workload), whereas approach needs (e.g., need for competence) are more likely to result in approach-focused crafting efforts (e.g., developing new skills, expanding one's work tasks). The (mis)match between crafting motives and efforts reveals when and why crafting efforts may (not) be effective in achieving optimal functioning. That is, our model postulates that crafting efforts are not equally effective in attaining optimal functioning. To be effective, crafting efforts should target unfulfilled needs. For instance, if an employee is motivated to satisfy specific psychological needs (e.g., she perceives a discrepancy between her actual and ideal level of relaxation) but directs behaviors in a manner incommensurate with its satisfaction (e.g., she engages in crafting behaviors centered around establishing social relationships), she will not achieve optimal functioning (e.g., Hofer \& Busch, 2011; Schüler, Job, Fröhlich, \& Brandstätter, 2008; Sheldon, Abad, \& Hinsch, 2011). 
Fifth, a model of crafting grounded in the Two-Process Model of Needs (Sheldon, 2011) entails a dynamic understanding of crafting processes over time with a feedback loop between needs satisfaction and needs discrepancy. We rely on the two-paradigm approach of self-regulation (Vancouver, 2000), claiming that the effect of past crafting experiences on future crafting efforts depends on whether the effect is examined from a within- or betweenperson perspective. Crafting can be viewed as a continuous process and examined from a within-person perspective within an action sequence, past successful crafting experiences (i.e., higher needs satisfaction) reduce future crafting efforts because the discrepancy between actual need state and ideal levels of need satisfaction is reduced (i.e., control theory; Carver $\&$ Scheier, 1981). On the other hand, examined from a between-person perspective, past successful crafting behaviors are positively related to future crafting efforts because of their effect on an individual's perception of the effectiveness of crafting efforts (i.e., expectancy theory; Vroom, 1964). Our model enables future research to examine the temporal unfolding and interactions of crafting motives, crafting efforts, and optimal functioning over time.

\section{Divergent Crafting Perspectives on Motivation, Behaviors, Life Domains, and Outcomes}

We next describe the core dimensions - motives, behaviors, domains, and outcomes common to different models of and perspectives on crafting, using them as the building blocks for our theoretical integration below.

\section{Crafting Motives}

Psychological needs have often been conceptualized as what motivates crafting (e.g., Wrzesniewski \& Dutton, 2001). However, existing crafting models often confound the motivating aspects of psychological needs (i.e., needs discrepancy) for engaging in crafting with the satisfaction of those needs through crafting efforts as an outcome of crafting (i.e., needs satisfaction). Regarding the latter, Wrzesniewski and Dutton (2001) argued that employees engage in job crafting to assert control, create a positive self-image, and establish 
human connections with others, leading to an increased sense of meaning. Notably, these positive needs are fulfilled through job crafting. This conceptualization of crafting motives relies on individuals' motivations to satisfy needs considered universal human requirements conducive to well-being (e.g., Tay \& Diener, 2011). Similarly, Petrou and Bakker (2016) identified universal needs of human connection, goal setting, learning and personal development as motivations for leisure crafting.

Other crafting theories stress needs discrepancy, an individual's sense of a discrepancy between what the environment affords and what she requires. The conceptualization of job crafting based on the job demands-resources model (JD-R) identifies person-job misfit as the underlying motivation for job crafting (Tims \& Bakker, 2010). Accordingly, the motivation for crafting is the potential mismatch between an employee's abilities or interests and job demands. That is, crafting depends on the mismatch, real or perceived, between an actual job and the ideal job. Similarly, Berg, Grant, and Johnson (2010) identified unfulfilled callings at work as the underlying motivations for leisure crafting. Concerning boundaries between life domains, Bogaerts, De Cooman and De Gieter (2018) proposed that the match between boundary management preferences and supplies provided by the work environment determines whether employees perceive a harmonious work-life interface.

Crafting motives along these two themes, needs discrepancy and needs satisfaction, require clarification. Both have motivational ingredients; needs discrepancy drives crafting efforts while needs satisfaction is a goal or expected reward impelling crafting efforts. Importantly, they are distinguishable as they make different claims regarding their universality and specificity and their order in the crafting process (i.e., needs discrepancy precedes crafting efforts while need fulfillment occurs after crafting). 


\section{Crafting Behaviors and Cognitions}

Wrzesniewski and Dutton (2001) identified three job crafting strategies: task, relational, and cognitive. Task crafting refers to changes in the number, type, and scope of job tasks performed. Relational crafting describes proactive changes applied to an employee's social interactions and cognitive crafting encompass changes in the view of work.

On the other hand, job crafting research grounded in the job demands-resources (JDR) model centers on employees' actual behaviors to either decrease job demands or increase job resources (Bakker \& Demerouti, 2017; Nielsen \& Abildgaard, 2012; Tims \& Bakker, 2010; Zhang \& Parker, 2018). Others have emphasized crafting behaviors in terms of approach or avoidance in resolving experienced discrepancy (Bruning \& Campion, 2018; Mäkikangas, 2018; Rofcanin, Bakker, Berber, Gölgeci, \& Las Heras, 2018). The organizing principle here distinguishes types of regulatory focus (i.e., approach/avoid; promote/prevent) that encompass the different domain-specific behaviors. Crafting conceptualized in terms of regulatory focus (i.e., approach and avoidance) provides a broader level of integration than behavioral collections or domain-specific behaviors (Zhang \& Parker, 2018).

\section{Life Domains}

Crafting research has focused mainly on the work domain and factors enhancing or motivating individuals to shape their experiences at work (job autonomy and workload; Rudolph et al., 2017) in addition to the benefits of such behaviors (e.g., job engagement and performance; Demerouti, Bakker, \& Gevers, 2015; Nielsen \& Abildgaard, 2012; Petrou, Bakker, \& Van den Heuvel, 2017).

An emerging research stream addresses crafting outside the work context (e.g., leisure crafting) and at the interface of work and non-work domains (e.g., boundary crafting, timespatial crafting, informal work accommodations to family). This line of research is currently focused on work-related determinants of crafting. Unfulfilled callings at work (Berg, Grant, 
et al., 2010) and high strain jobs or jobs with few opportunities for crafting (Petrou \& Bakker, 2016) have been identified as factors motivating employees to engage in leisure crafting.

In contrast to the variety of crafting behaviors identified within the work domain, the non-work crafting literature does not capture these nuances. Leisure crafting has been mainly conceptualized as a single-dimension construct, encompassing various behaviors targeting non-work skills, activities, and relationships (Petrou, \& Bakker, 2016; Petrou et al., 2017). The literature on crafting at the interface of work and non-work domains has likewise identified concrete behavioral strategies (e.g., adjusting the timing, length, and the temporal experience of the working day, shielding private time, and using social relationships to facilitate work-, non-work balance; Behson, 2002; Gravador \& Teng-Calleja, 2018; Sturges, 2012; Wessels et al., 2019) while frequently ignoring cognitive crafting strategies. Moreover, the literature has generally disregarded a variety of non-work roles as domains amenable to crafting.

\section{Crafting Outcomes}

As crafting studies have usually focused on one single domain, the outcomes considered in the crafting literature are generally domain-specific. The most studied outcomes of job crafting include work-related well-being and job performance (see Table 1). Key variables within this category are work engagement, vitality, job strain, fatigue, job satisfaction, and job performance (e.g., Bruning \& Campion, 2018; Tims \& Bakker, 2010). Studies on the non-work domain or the interface between life domains have primarily focused on general well-being (e.g., eudaimonic and hedonic well-being, resilience, thriving, work-life balance, conflict or role identification; e.g., Petrou \& Bakker, 2016; Wessels et al., 2019) as outcomes. An integrative model of crafting across different life domains will provide a panorama of desired states by which to empirically evaluate crafting effectiveness and consider when and how outcomes may be improved across different domains. 


\section{Crafting Redefined: The Integrative Needs Model of Crafting}

We view crafting as substantial behavioral and cognitive changes individuals deliberately apply to their roles to satisfy their psychological needs. We identify five characteristics of crafting based on the four questions: 1) why, 2) how, 3) who, and 4) what.

The first question is "why", referring to the reasons for engaging in crafting. Crafting is proactive (Berg et al., 2013), occurring when there is a discrepancy between the actual and ideal level of needs satisfaction or in anticipation of future needs discrepancy. This characteristic distinguishes crafting efforts from constructs like coping, which is reactive and a response to stressful events, past or present. This also means that crafting is intentional (e.g., Wrzesniewski \& Dutton, 2001), referring to deliberate, goal-directed attempts to reduce the distance between ideal and current levels of need satisfaction. This distinguishes crafting from subconscious or automatic reactions. Accordingly, some of people's recreational activities that are non-deliberative, routine, or automatic during off-job time are not considered crafting.

The second question is "how" people craft, referring to the process of crafting. Crafting is fundamentally a bottom-up process that is self-initiated (Tims et al., 2012). It is motivated by the person herself and thus differs from top-down processes like formal job redesign initiated by the organization. The third question is "who", referring to the target of crafting. Crafting is self-targeted (e.g., Tims et al., 2012), aimed at satisfying a person's individual needs, thus differing from attempts to benefit others, like organizational citizenship behaviors typically aimed at helping the organization or colleagues.

The final question is focused on "what", referring to the magnitude and observability of crafting. Crafting efforts are substantial (e.g., Berg, Wrzesniewski, \& Dutton, 2010), with a clear and enduring difference between a person's crafted and pre-crafted behaviors. Even if behavioral changes are minor (e.g., integrating three minutes of breathing exercises on three 
days per week), they count as crafting if they are apparent to the person herself and represent a new routine. This also means that crafting concerns mid-term or long-term behavioral and cognitive changes rather than incidental or singular changes (e.g., Bruning \& Campion, 2018). It refers to establishing new relatively permanent habits or more sustained routines. This distinguishes crafting from ad-hoc behaviors, frequently a response to acute physiological urges like pain, hunger or fatigue.

Given this definition, crafting related to both an identity perspective and a psychological needs perspective. People engage in crafting across their numerous identities within and across life domains (i.e., work and non-work); and these role changes reflect changes in the within-person norms. A change is considered crafting if there is a substantial deviation from the person's typical behaviors or cognitions within a role. Furthermore, psychological needs motivate crafting efforts within each identity domain; the discrepancy between a person's ideal level and actual level of needs satisfaction motivates individuals to engage in crafting efforts within an identity domain. We elaborate on these propositions below.

\section{Crafting: An Identity Perspective}

The identity literature has long accepted an individual's self-concept as a complex phenomenon comprising multiple identities across both work and non-work domains (Ramarajan, 2014; Stryker \& Burke, 2000). Our theoretical framework posits that individuals may engage in crafting efforts within each identity domain. The notion of multiple identities is implicit in the crafting literature. For example, Wrzesniewski and Dutton (2001) identify the changes in work identity, defined as "the attributes and the more holistic conception that people have of themselves at work" (p. 180) as an outcome of job crafting, recognizing that identity is an important element of the crafting process. Similarly, in the identity literature, while the concept of crafting is rarely invoked, many related phenomena have similar 
connotations. For instance, the literature on identity work emphasizes individuals' active role in constructing and negotiating their identities in social contexts (Pratt, Rockmann, \& Kaufmann, 2006; Snow \& Anderson, 1987). The literature incorporates various strategies that individuals use to construct and manage their identities at work, ranging from cognitive strategies (e.g., narrative work; Ibarra \& Barbulescu, 2010) to concrete behaviors (e.g., segmentation tactics; Kreiner, Hollensbe, \& Sheep, 2006).

Given the implicit, yet significant, relevance of identity within the crafting process, our theoretical framework of crafting posits its occurrence within each identity domain. For instance, individuals may craft to enhance the sense of belonging as an employee, parent, spouse, or volunteer. Our model further posits that individuals may make distinct crafting efforts across identity domains. Although these differences may be less notable with identities that are less distinguishable or often simultaneously activated (e.g., employee and co-worker identities; spouse and parent identities), important differences in crafting nevertheless exist across identity domains. Such differences have two possible origins. First, different strategies may be used to address the same need; a person may act differently as a father (e.g., reading a book on child nutrition) than as an employee (e.g., accepting a more challenging job task) to satisfy his need for competence. Second, the types of needs addressed across identity domains may differ, with some more easily satisfied in certain roles than in others. For instance, the need for competence may be more easily satisfied in a professional work identity than in a non-work identity. Given our broad focus on approach vs. avoidance crafting (to be discussed later), we focus primarily on the differences in types of needs addressed across identity domains. We elaborate on these below.

\section{Crafting: A Psychological Needs Perspective}

Given the multiplicity of views and divergent emphases within the crafting literature, an integrative model that accounts for motivated crafting efforts across life domains is 
imperative to resolve inconsistencies and provide a theoretical synthesis. Furthermore, while past crafting theories acknowledged the importance of individual needs in motivating crafting efforts and that such drivers closely resemble psychological needs as defined in major need theories (i.e., particularly self-determination theory; Ryan \& Deci, 2000), no explicit link between crafting and psychological needs has so far been established. Connecting crafting research to need theories will provide new avenues for research by providing a framework connecting behaviors and experiences occurring in different identity domains via universal psychological needs.

Accordingly, our Integrative Needs Model of Crafting (Figure 1) integrates past research using the Two-Process Model of Needs (TPM; Sheldon, 2011) that differentiates between needs discrepancy and needs satisfaction. In line with the TPM, we argue that psychological needs are simultaneously motivators of crafting efforts (i.e., needs discrepancy) and outcomes of the crafting process (i.e., needs satisfaction). We elaborate on this below, discussing how divergent views on crafting motives, efforts, life domains, and outcomes are integrated.

\section{Crafting Motives}

Following the TPM, psychological needs serve as both behavioral energization in crafting (i.e., needs discrepancy) and experiential reward for engaging in crafting efforts (i.e., needs satisfaction). Distinguishing between needs discrepancy and needs satisfaction in the crafting process enables us to reconcile the disparate views on crafting motivation. Specifically, needs discrepancy emphasizes the fit between individual motives and actual crafting efforts, and suggests individual differences in preferences and values due to differences in upbringing, personality traits, and socialization (McClelland, 1985), at the outset of the crafting process (Paths P1 and P2 in Figure 1). On the other hand, needs satisfaction experienced at the conclusion of crafting efforts (Paths P3 and P4 in Figure 1) is 
based on organismic theories (Deci, Olafsen, \& Ryan, 2017; Ryan \& Deci, 2000) wherein individuals share common needs that, when satisfied, lead to optimal functioning. Needs discrepancy and needs satisfaction are connected via a feedback loop, comparing ideal and actual states in needs satisfaction. Accordingly, the Integrative Needs Model of Crafting not only distinguishes different crafting motives but also serves as a basis for how crafting processes unfold dynamically over time.

Proposition 1: Needs discrepancy is salient at the inception of crafting efforts, whereas needs satisfaction occurs toward the conclusion of crafting efforts.

\section{Psychological Needs}

Theories on psychological needs date from the 1930s and the emergence of humanistic psychology rooted in organismic theories viewing humans as active, growthoriented beings with an inborn integrative tendency (Hull, 1943; Maslow, 1943; Murray, 1938). In more recent theories, needs are seen as requirements (i.e., independent of individual or cultural differences), which foster psychological growth, well-being, and optimal functioning (e.g., Chen et al., 2015; Tay \& Diener, 2011; Van den Broeck, Ferris, Chang, \& Rose, 2016).

Importantly, there is ample research showing that a small set of psychological needs constitutes a species-typical feature of human nature (Tooby \& Cosmides, 1990), hence some needs are considered universal across people and cultures and largely explain human behavior (e.g., Tay \& Diener, 2011). The most widely accepted universal psychological needs are autonomy, relatedness, and competence in today's self-determination theory (Ryan \& Deci, 2000) but many other needs have also been proposed and examined (e.g., meaning, 
pleasure, safety, self-esteem, power, growth, achievement, beneficence; see for example Martela \& Riekki, 2018; Sheldon, Elliot, Kim, \& Kasser, 2001)².

Rather than detailing different needs, we focus on broader categories of approach and avoidance needs as proposed by Green, Finkel, Fitzsimons, and Gino (2017). Approach needs pursue a positive state and are centered on growth, enrichment, and the creation of new resources. People's desire to learn something new, to master a new skill, to feel competent and socially connected are examples of approach needs (e.g., Newman, Tay \& Diener, 2014; Ryan \& Deci, 2000; Ryff \& Keyes, 1995). Conversely, avoidance needs are precipitated by the desire to avoid negative outcomes and refer to people's desire to decrease physical and/or mental effort investment, to optimize levels of cognitive stimulation (e.g., Tinsley \& Eldredge, 1995) and to restore homeostatic balance. Relaxation (Sonnentag \& Fritz, 2007 \& 2015), safety, and security (Green et al., 2017) are examples of such needs. These broad categories of needs can be mapped onto different crafting efforts and help to integrate crafting across identity domains and predict differential effects on optimal functioning (see also Zhang \& Parker, 2018).

The psychological needs perspective can also be found in the identity literature. Specifically, the identity construction literature suggests that individuals affiliate more strongly with identities that satisfy the primary motives for identification, including selfesteem, belongingness, meaning, distinctiveness, efficacy, and continuity motives among others (Ashforth, 2001) having similar connotation with psychological needs. Although the literature mainly discusses these motives in terms of identity construction, satisfaction of these motives within each identity over time can also influence subsequent importance,

\footnotetext{
${ }^{2}$ We note that while these psychological needs span identities, they may be fulfilled in unique ways within specific identities. For example, the psychological need for relatedness may be uniquely fulfilled by having a life partner within a person's spousal identity whereas it may be uniquely fulfilled by having great work colleagues within work identity.
} 
salience, and enactment of an identity (Vignoles, Regalia, Manzi, Golledge, \& Scabini, 2006) and individuals strive to satisfy these motives every time the identity is enacted (Vaziri, 2018). It has been demonstrated, for instance, that individuals engage in identity work to maintain identity motives such as belongingness, self-enhancement, and selfverification (Caza, Vough, \& Puranik, 2018). Similarly, individuals arguably (re)craft their narratives partly to satisfy their needs, leading to higher fit perceptions (Shipp \& Jansen, 2011). Such findings suggest that "[...] identities motivate behaviors that have meanings consistent (isomorphic) with the identity" (Burke \& Reitzes, 1981, p. 83). Accordingly, from a crafting perspective, individuals may engage in crafting efforts to satisfy identity motives rooted in psychological needs. Thus, we propose:

Proposition 2: Perceived approach and/or avoidance needs discrepancies motivate crafting efforts.

Approach and avoidance need discrepancies occur due to some lack within a domain (e.g., insufficiently engaging work leads to an approach need discrepancy) or an excess (e.g., excessively engaging in work leads to an avoidance need discrepancy). Both types of need discrepancies can be triggered (a) simultaneously for a specific domain due to different types of needs (e.g., needing more social support while also needing to find more time to relax at work) or (b) for different domains (e.g., needing to unwind outside of work while needing to find more autonomy at work).

\section{Crafting Efforts}

In our model, we integrate crafting efforts in line with regulatory focus (Elliot, 2006; Higgins, 1998) as it represents a broader level of organization (see also Bindl et al., 2018; Bruning \& Campion, 2018; Rofcanin et al., 2018). We adopt the hierarchical structure of crafting proposed by Zhang and Parker (2018) and define approach-focused crafting as intended to add various aspects to work or non-work roles to satisfy psychological needs, 
whereas avoidance-focused crafting refers to diminishing undesirable aspects of a work or non-work role to satisfy psychological needs. Research on identity work adds new perspectives to crafting efforts. A recent review (Caza et al., 2018) summarizes identity work modes which help people reshape their identities to match their personal needs categorized into cognitive (e.g., cognitive reframing of meaning attached to occupation, recalibrating internal standards, repositioning organizational practices, selective processing of information), discursive (e.g., using insider jargon, humor, irony), and physical modes (e.g., using one's own body, materials or objects in physical environments to match a desired identity). In general, we expect that the type of crafting efforts people engage in is dependent on perceived psychological needs discrepancy. Psychological needs as motives are partly inherited, partly acquired stable preferences for certain incentives in the environment (Atkinson, 1992). According to Motive Disposition Theory (MDT), individuals differ in their motive dispositions, defined as “[...] learned or acquired orientations toward certain natural incentives in the environment" (Sheldon \& Schüler, 2011, p. 1107). MDT research typically focuses on individual differences in motives and their accompanying effects on behaviors, demonstrating that people 1) tend to engage in behaviors which match their individual motives and 2) particularly benefit from satisfaction of needs aligning with their individual motives (e.g., Schüler, Brandstätter, \& Sheldon, 2013).

Applied to the crafting context, approach needs discrepancy should more often result in approach crafting behaviors whereas avoidance needs are expected to prompt avoidance crafting behaviors. Empirical studies also support this proposition. For example, the motive dispositions "need for achievement" and "need for intimacy" are related to matching goal strivings in the corresponding domain (i.e., agency and communion goals) and having these motives also predicted satisfaction of the corresponding needs, presumably due to greater perseverance, confidence, and resilience in pursuing goals consistent with motives (Sheldon 
\& Cooper, 2008). Similarly, induced autonomy deprivation can lead to behaviors which specifically seek to restore lost autonomy (Radel, Pelletier, Sarrazin, \& Milyavskaya, 2011) and approach (but not avoidance) work motivation has been found to positively relate to corresponding approach behaviors such as organizational citizenship behaviors (Johnson, Chang, Meyer, Lanaj, \& Way, 2013). In summary, we propose:

Proposition 3: Approach needs discrepancy is more strongly associated with approach-focused crafting efforts, while avoidance needs discrepancy is more strongly associated with avoidance-focused crafting efforts.

Importantly, because needs are holistically fulfilled across different identity domains, effective crafting efforts require consideration of different domains for individuals. For example, crafting in the work role to address approach needs discrepancy due to lack of autonomy at work may also be conjoined with crafting in the family role to address avoidance needs discrepancy due to lack of time to assume more responsibility at work (see for instance Hewett et al., 2017). As such, addressing needs discrepancies through crafting requires consideration of different identity domains. For illustrative examples of needs and crafting efforts across different identities, see Table 2.

\section{Crafting Across, Within, and Between Identity Domains}

The crafting process proposed in our Integrative Needs Model of Crafting based on the TPM is a general psychological process applying across life domains, usable for understanding crafting efforts across a multitude of individual identities. This synthesis of a common crafting process is vital; fulfillment of psychological needs in the crafting process constitutes the basis of human behavior and cannot easily be isolated into any single identity domain. It requires a holistic approach to crafting behaviors across different identity domains to fulfill psychological needs. Further, technological advances and other major societal changes, such as social acceleration (Rosa, 2013), blur the boundaries between identity 
domains, particularly between work and non-work identities. Crafting motivations and behaviors are consequently interdependent across identity domains and crafting experiences within one identity domain may influence crafting efforts in another. Indeed, studies have demonstrated that unfulfilled needs at work increase individual motives for leisure crafting (Petrou et al., 2017; Petrou \& Bakker, 2016).

Accordingly, as psychological needs pertain to work and non-work identities, we treat crafting across identity domains as interrelated to similar underlying motives. As noted, crafting efforts may also occur within the domain of each (role) identity an individual assumes. Crafting efforts may be domain-specific and need discrepancies may be felt more strongly within a particular role. Drawing on SDT, Deci and Ryan (2008) proposed that domains (e.g., workplace, home, sports, and leisure) can be differentiated by the type of need fulfillment they support, implying that there are likely differences in the degree of need discrepancies experienced across different roles. Indeed, research has shown that the amount of need satisfaction (autonomy, competence, and relatedness) within different life domains such as work, family, and activities differs significantly (e.g., Milyavskaya \& Koestner, 2011; Ryan, Bernstein, \& Brown, 2010), suggesting that certain needs are more relevant within certain life domains.

Likewise, from an identity perspective, as discussed, individuals identify more strongly with identities that satisfy identification motivations (i.e., psychological needs). However, different types of identities satisfy these motives to differing extents. Personal identities are more likely to satisfy the distinctiveness motive, whereas collective identities are more likely to satisfy the belongingness motive (Vignoles et al., 2006). Various types of personal identifications (threat-focused, opportunity-focused, and closeness-focused) have been posited to satisfy different personal goals (i.e., needs) such as uncertainty reduction, self-enhancement, and belongingness (Ashforth, Schinoff, \& Rogers, 2016). Accordingly, 
certain needs may be more salient or relevant in particular identity domains, thus motivating crafting effort in that domain.

Proposition 4: Experienced approach and/or avoidance needs discrepancy are identity-specific, resulting in crafting efforts within a particular identity domain.

Crafting may also occur at the interface of identities; we propose two such categories of crafting. Firstly, crafting efforts may be targeted at the boundaries between different identity domains (e.g., segmenting identities from one another). Secondly, crafting can target multiple identities simultaneously (e.g., crafting to be perceived both as a caring mother and a motivated employee).

Crafting efforts targeting the boundaries between identity domains closely resemble what the literature calls boundary management (Ashforth, Kreiner, \& Fugate, 2000; Bulger, Matthews, \& Hoffman, 2007; Clark, 2000). The literature identifies flexibility and permeability as two features of boundaries between domains and suggests that individuals are active in shaping the flexibility and permeability of domains (Clark, 2000). Accordingly, we propose that behavioral strategies targeting these boundaries can be understood as crafting efforts at the interface of identity domains. For instance, individuals' strategies to segment or integrate life domains (Kreiner, Hollensbe, \& Sheep, 2009) and also to manage transitions from one role to another (e.g., micro role transitions, see Ashforth et al., 2000) can be considered instances of crafting at the interface of identities.

Most instances of crafting efforts targeting multiple identities simultaneously have been described in identity research. For instance, Burke (2006) identifies one way through which identities change if multiple identities are activated together, whose verifications require opposing meanings to be manifest in a person's behavior. Such crafting is commonly discussed within the multiple identities and diversity literature. It has been suggested that individuals with stigmatized invisible identities decide to either hide or reveal their 
stigmatized identities at work (a form of crafting at the interface) based partly on their personal motives, such as maintaining self-esteem and building relationships (Clair, Beatty, \& MacLean, 2005). Similarly, women may engage in distinct strategies (e.g., passing, downplaying) to construct their identity and image as mothers and professionals during pregnancy (Ladge, Clair, Greenberg, 2012; Little, Major, Hinojosa, \& Nelson, 2015).

Individuals may also engage in cognitive crafting to reconcile inconsistency in meaning across their multiple identities. A person's gender identity may call for strength and masculinity, while his father identity may call for solicitude, tenderness, and femininity. Simultaneous activation makes mismatching identities inevitable; meanings of identities will shift towards commonality. We consider the cognitive work a person needs to undertake to achieve this change in identity to satisfy the five requirements of crafting (e.g., intentional) as an instance of crafting at the interface. Similarly, identity work modes (i.e., cognitive, discursive, physical; Caza et al., 2018) can be considered specific types of crafting at the interface between identity domains. Our model can serve as a conceptual basis for existing studies by suggesting relevant drivers motivating people to engage in crafting efforts, and contextual variables that potentially affect which needs will be addressed. By providing an overarching theoretical framework, our model establishes common ground between hitherto unconnected streams of research and affords new insights.

\section{Crafting Outcomes}

Psychological needs are thus an intermediate outcome of crafting efforts (Paths P5 and P6 in Figure 1) and the motivating force for optimal functioning. Accordingly, crafting efforts will achieve needs satisfaction, which subsequently enhances optimal functioning (e.g., Rudolph et al., 2017; Van den Broeck et al., 2016). These relationships have been well established in earlier research. For instance, research has demonstrated links between leisure crafting and needs satisfaction (Petrou \& Bakker, 2016), between needs satisfaction and well- 
being (for a review, see Deci \& Ryan, 2008, Tay \& Diener, 2011; Van den Broeck, Ferris, Chang, \& Rosen, 2016) as well as between job crafting, needs satisfaction and well-being (e.g., Slemp \& Vella-Brodrick, 2014).

\section{Proposition 5: Crafting efforts increase optimal functioning through needs} satisfaction.

Relying on the identity-matching principle (Ellemers \& Rink, 2005; Ullrich, Wieseke, Christ, Schulze, \& Van Dick, 2007), we posit that crafting efforts within an identity domain are most strongly related to optimal functioning within the same domain (proximal) rather than a different domain (distal). This concurs with Amstad, Meier, Fasel, Elfering, \& Semmer (2011) and Shockley and Singla's "source attribution framework" (2011), predicting that employees will more likely attribute well-being within a domain to crafting accomplished within the same life domain. For example, if a person actively crafts at work to develop more meaningful relationships (i.e., approach-focused crafting efforts), she will experience higher job satisfaction. In the work domain, proximal crafting outcomes are better work-related well-being (e.g., work engagement, job satisfaction) and enhanced job performance (e.g., task performance, extra-role performance). In the non-work domain, optimal functioning corresponds to general well-being (e.g., happiness, positive affect, life satisfaction) and enhanced non-work role performance (e.g., family role performance, relationship performance; see Chen et al., 2014). Accordingly, we formulate the following proposition.

Proposition 6: Crafting efforts result in higher optimal functioning within the same

\section{identity domain.}

\section{Individual and Contextual Factors}

Our model also incorporates individual and contextual factors from the literature (Paths P7 and P8 in Figure 1). These factors influence the crafting process both directly, through their effects on the salience of needs and the degree of perceived needs discrepancy 
(i.e., direct antecedents of crafting motives), and indirectly, through their effects on the strength of the relationships between needs discrepancy and crafting efforts.

Research on crafting has discussed a variety of individual difference factors (e.g., age, career stage, gender, employment status, type of work, education, personality, regulatory focus, coping styles) possibly affecting the extent to which individuals engage in crafting (e.g., Lyons, 2008; Rudolph et al., 2017; see Zhang \& Parker, 2018, for a comprehensive review). Furthermore, an important individual factor is identity centrality within the crafting process. Role or identity centrality (Stryker \& Serpe, 1994) indicates how important a person considers certain identities or life domains. People are generally willing to invest more time and energy in more central identities (e.g., Greenhaus \& Beutell, 1985). For instance, organizational identification has been found to relate positively to crafting behaviors at work (Lin, Law, \& Zhou, 2017; Wang, Demerouti, \& Le Blanc, 2017). The centrality of work or non-work in a person's life moreover determines whether perceived needs discrepancy motivates her to engage in crafting efforts (e.g., Lin et al., 2017). We argue that individuals are more likely to engage in crafting efforts in more central identity domains, potentially leading to role expansion. As we deem approach-focused crafting more effortful than avoidance-focused crafting (e.g., acquiring new skills or engaging in meaningful social interactions require self-regulation and may be difficult at times; see argumentation on recovery experiences by Sonnentag \& Fritz, 2007), approach-focused crafting is also more likely within central identities or life domains, whereas avoidance-focused crafting is more likely within peripheral life domains, where people want to minimize effort investment. Contextual factors presumably also influence the crafting process because they determine the salience and relevance of particular needs (Chen et al., 2015; Salancik \& Pfeffer, 1978) and the specific crafting strategies people engage in when motivated by a 
particular need. Contextual variables can be organized into stable and transient factors.

Regarding (relatively) stable factors, the cultural context is the common background against which needs are developed, perceived, and (possibly)satisfied. Culture influences individuals' behaviors within a society through their interpretations of situational and environmental cues through social learning and repeated contact with situations conducive to similar ways of thinking (Gibson, Maznevski, \& Kirkman, 2009; Peterson \& Barreto, 2014; Peterson \& Wood, 2008). For instance, the significance of leisure and work varies widely among cultures and may be gendered, with women usually having significantly less leisure time than men (Iwasaki, 2007; Shaw, 1985; Thrane, 2000). Homogeneity in values, norms, and behaviors (i.e., cultural tightness, Gelfand, Nishii \& Raver, 2006; Uz, 2015) within a country may also explain differences between countries regarding perceived needs discrepancies and crafting efforts undertaken to redress them. Cross-cultural research on crafting is rare. A few pioneering studies have been conducted in Western and Asian cultures (Gordon, Demerouti, LeBlanc, \& Bipp, 2015; Nielsen, Antino, Sanz-Vergel, \& RodríguezMuñoz, 2017; Yepes-Baldo, Romeo, Westerberg, \& Nordin, 2018), lending preliminary support to the significance of culture in the crafting process.

The organizational or family context may also dictate which needs are prioritized and whether crafting motives actually transform into crafting efforts. According to SDT, an autonomy-supportive context facilitates the satisfaction of psychological needs by enhancing persistence and effective performance (Deci \& Ryan, 2008; Sheldon \& Elliot, 1999; Vansteenkiste, Simons, Lens, Sheldon, \& Deci, 2004). Accordingly, various contextual characteristics across life domains supporting individual autonomy may facilitate crafting efforts and subsequently promote optimal functioning. Various work-related contextual factors, notably job autonomy and workload, and their effects on crafting behaviors have been scrutinized (e.g., Bakker \& Demerouti, 2017; Tims, Bakker, \& Derks, 2013). Less 
studied factors include job characteristics (e.g., task identity, significance, and interdependence; Kim \& Lee, 2016;) and social support (e.g., LMX, feedback, peer support; Berdicchia \& Masino, 2017; Radstaak \& Hennes, 2017). This research, however, is typically confined to the direct effects of contextual factors on crafting behaviors, suggesting that these factors are directly related to various crafting behaviors (Rudolph et al, 2017) because they provide individuals with resources or motivation for crafting. The moderating role of these factors requires attention.

Similarly, the effects of non-work contextual factors on job crafting are poorly understood. To the best of our knowledge, only one study has examined the impact of nonwork contextual factors on leisure crafting (Petrou \& Bakker, 2016). For example, a person's family status may determine how much time she has for new hobbies. People also learn about needs and what these could or should be from interactions with close others (e.g., family members, colleagues; see Salancik \& Pfeffer, 1978), thus need (non)satisfaction is contingent upon the social environment (e.g., Soenens \& Vansteenkiste, 2010; Thøgersen-Ntoumani, Ntoumanis, \& Nikitaras, 2010) with multilevel approaches needed to disentangle group- and individual-level processes.

Finally, various transient situational factors may influence the salience of needs or needs discrepancy, likewise the opportunity for certain crafting behaviors when motivated by disparate needs. For instance, temporary changes in tasks, workload or mood states (e.g., feeling tired; see Hülsheger, 2016) may result in certain needs discrepancies (e.g., avoidance needs), which motivates individuals to engage in crafting efforts (e.g., avoidance-focused crafting; Petrou, Demerouti, Peeters, Schaufeli, \& Hetland, 2012). For example, daily variation in workload may increase or reduce opportunities to engage in crafting. Similarly, we assume that employees craft to adjust to new life circumstances such as promotion within the company or having a child (e.g., Ladge et al., 2012; Little et al., 2015; Wessels et al., 
2019).

Proposition 7: Individual and contextual factors influence the crafting process directly (through their effects on the salience of needs discrepancy) and indirectly (through their effects on the strength of the relationships between needs discrepancy and crafting efforts).

\section{Matching Process between Needs Discrepancy and Crafting Efforts}

We propose that it is essential to consider the match between needs discrepancy (i.e., approach and avoidance needs) and crafting efforts (i.e., approach and avoidance focus) in achieving optimal functioning. That is, to be effective in achieving optimal functioning, crafting should target the discrepant needs. Optimal functioning can be achieved if 1) people accurately perceive the needs which are not fulfilled and 2) engage in crafting efforts to address the imbalance in needs. This aspect of the model is grounded in functional homeostatic regulation and, more specifically, the Demand-Induced Strain Compensation (DISC) model (De Jonge \& Dormann, 2003; De Jonge \& Dormann, 2006). The DISC model states that specific job demands (i.e., cognitive, emotional, physical) are buffered most effectively by matching job resources rather than less-matching or non-matching job resources (for a review of the empirical evidence of the DISC model, see De Jonge, Dormann, \& Van den Tooren, 2008). Following this matching principle of the DISC model, an imbalance in needs satisfaction induces corresponding crafting to redress the perceived imbalance, resulting in needs satisfaction and ultimately improved well-being and performance. The Integrative Needs Model of Crafting proposes that high approach needs are more likely to result in approach-focused crafting efforts, whereas high avoidance needs are more likely to result in avoidant-focused crafting efforts. However, due to erroneous perceptions, a person's crafting efforts may not match her actual needs, or individual and contextual factors may limit accomplishing certain crafting efforts. Whenever such a 
mismatch between crafting motives and crafting efforts occurs, discrepant psychological needs will not be satisfied, and optimal functioning cannot be achieved.

Proposition 8: Approach crafting efforts are more effective if addressing an approach needs discrepancy, whereas avoidance crafting efforts are more effective if addressing an avoidance needs discrepancy.

The match between a person's perceived needs discrepancy and actual crafting efforts may determine the extent to which crafting results in optimal functioning. Differentiating between crafting motives and actual crafting efforts and their potential misalignment affords new avenues for research, thereby addressing inconsistencies found in earlier crafting studies. For instance, crafting behaviors aimed at lowering job demands have inconsistent effects on work-related well-being (e.g., Rudolph et al., 2017; Van Wingerden, Derks, \& Bakker, 2017). By taking account of people's motives for engaging in approach-focused crafting efforts and the potential mismatch between their motives, actual crafting efforts and needs satisfaction, we may be better able to explain why certain crafting efforts have no beneficial or even negative effects on optimal functioning.

\section{Dynamics of the Crafting Process}

Our integrative model (Figure 1) considers explicitly and implicitly the crafting process as a dynamic phenomenon in at least two important ways: (a) crafting processes and feedback loops; (b) interactions between identity domains through compensation and spillover processes. Regarding the former, our conceptual model delineates how the crafting process evolves through needs discrepancy $\rightarrow$ crafting behaviors and cognitions $\rightarrow$ needs satisfaction $\rightarrow$ optimal functioning. Further, the model also proposes a feedback loop from needs satisfaction to needs discrepancy, suggesting that past crafting experiences influence future motivation to craft. The latter entails explicating how crafting motives, efforts, 
cognitions, and outcomes are intertwined across identity domains through mechanisms of spillover, compensation, and conflict.

\section{Temporal Dynamics of Crafting}

Our integrative model considers crafting as a process composed of behavioral episodes centered around perceived needs, which motivate crafting efforts, potentially leading to needs satisfaction, which in turn rewards crafting efforts. This process can be viewed from the test-operate-test-exit sequence (TOTE; Miller, Galanter, \& Pribram, 1960). The crafting process starts when an individual recognizes needs discrepancy (i.e., need satisfaction differs from ideal; test) and she will act to remedy the discrepancy through crafting efforts (operate). She tracks her progress within the process (test) until her psychological needs are satisfied, which leads to the termination of the process (exit). From this perspective, needs discrepancy and needs satisfaction are closely related, but occur at different time points during an action sequence (see also Sheldon, 2011). Accordingly, it is crucial that the crafting process is examined from a temporal perspective examining two key processes of 1) the crafting process in a particular behavioral episode (i.e., needs discrepancy $\rightarrow$ crafting efforts $\rightarrow$ needs satisfaction $\rightarrow$ optimal functioning), and 2) the crafting process across multiple behavioral episodes (i.e., past crafting experiences $\rightarrow$ future crafting efforts).

Table 3 presents illustrative examples of research focusing on different phases of the crafting process (i.e., needs discrepancy $\rightarrow$ crafting efforts, crafting efforts $\rightarrow$ needs satisfaction, and crafting efforts $\rightarrow$ optimal functioning $\left.{ }^{3}\right)$. Given the paucity of empirical studies on crafting processes from an identity perspective, we have organized them into broad domains of work, non-work, and interface crafting. While these studies are helpful in extending our understanding of the crafting process, few studies examine a temporal

\footnotetext{
${ }^{3}$ We excluded the link between needs satisfaction and optimal functioning given the abundance of reviews focusing on this relationship (e.g., Czekierda, Banik, Park, \& Luszczynska, 2017: Van den Broeck et al., 2016).
} 
perspective. These studies typically lend support to the lagged relationship between needs discrepancy and crafting efforts as well as crafting and needs satisfaction. For instance, the need for positive self-image was positively related to job crafting with a two-week lag (Niessen, Weseler, \& Kostova, 2016). Needs for autonomy, competence, and relatedness measured in the morning were positively related to approach and avoidance crafting at the end of the day (Bindl et al., 2018). In addition, job crafting was found to be a positive predictor of needs satisfaction and meaningfulness after two weeks (Tims, Derks, \& Bakker, 2016) and after three months (Lu, Wang, Lu, Du, \& Bakker, 2014). However, none of these studies examined whether needs satisfaction occurs after a specific crafting action sequence from a within-person perspective.

Importantly, the Integrative Needs Model of Crafting proposes that past experiences of crafting influence future crafting efforts (Path P9 in Figure 1), which has not been explored before. This process is characterized by a feedback loop from needs satisfaction to needs discrepancy (Path 9 in Figure 1) and can be viewed from both between- and within-person perspectives. From a between-person perspective, successful past crafting efforts (i.e., high needs satisfaction) are likely to energize people to engage in more crafting (e.g., to craft in other identity domains) through their effects on perceptions of effectiveness or the instrumentality of crafting efforts in boosting needs satisfaction (i.e., perception of the strength of effort-outcome relationship). From a within-person perspective, motivation for further crafting within a domain diminishes with successful crafting within an action sequence as unmet needs become satisfied. This is in line with the two-paradigm perspective on the effect of self-efficacy on performance (Vancouver, Thompson, Williams, 2001). The literature on self-efficacy adopts two paradigms of decision-making and cybernetic systems (Vancouver, 2000), suggesting that between-person differences in self-efficacy are positively related to performance, whereas self-efficacy at the within-person level is negatively related 
to performance (Vancouver et al., 2001).

The two-paradigm approach can also be integrated into the within-person level decision-making process of crafting. The cybernetic paradigm (e.g., control systems; Carver and Scheier, 1981), common in mechanical systems, can be applied to the crafting process at the within-person level. That is, the system works by constructing a perception of the current state of psychological needs and compares this perception to the goal. The discrepancy between the goal and the current state motivates individuals to engage in crafting to remedy the discrepancy. Given that these actions reduce the discrepancy between perception and goal (i.e., needs satisfaction), a negative feedback loop exists that decreases the motivation to engage in crafting. This process would be in effect when examining the crafting process within an action sequence to enhance needs satisfaction. Accordingly, we propose:

Proposition 9: Within-person changes in needs satisfaction are negatively related to crafting motivation within an action sequence.

The decision-making paradigm can also be applied to the crafting process at the between-person level. One of the most commonly used theories within the decision-making paradigm is expectancy theory (Vroom, 1964), which suggests that self-regulation and decision-making are based on the subjective perception of expected utility of options based on the perceptions of (a) the effort-behavior relationship (i.e., expectancy), (b) the behavioroutcome relationship (i.e., instrumentality), and (c) the desirability of the outcome (i.e., valence). Applied to the crafting process, individuals' motivation to engage in crafting increases as they perceive (1) that they have the necessary resources and skills to engage in crafting, (2) that their crafting efforts are effective in satisfying their needs, and (3) that needs discrepancy is considered personally salient. Within this process, successful crafting experiences (i.e., high needs satisfaction as a result of a crafting action sequence) can further increase the perception of the effectiveness of crafting in satisfying psychological needs (i.e., 
instrumentality link). This process results in higher motivation to engage in future crafting. Such motivation may entail continuing the crafting process at work, engaging in similar crafting behaviors over time, or deciding to craft in other identity domains as well. Thus, we propose:

Proposition 10: Between-person changes in needs satisfaction are positively related to future crafting motivation.

Accordingly, it is likely that crafting follows certain trajectories over time. For "crafters" there may be a positive trend in well-being and performance over time. However, if crafting repeatedly fails to achieve needs satisfaction (i.e., experiential rewards fail to materialize), people may give up crafting. If this happens repeatedly and in several life domains, people may end up in a situation resembling learned helplessness and absence of proactive behaviors (for a discussion on similar trajectories with regard to psychological resources, see Halbesleben, Neveu, Paustian-Underdahl, \& Westman, 2014).

Proposition 11: Past positive experiences of crafting influence future crafting efforts.

\section{Crafting Dynamics across Identity Domains}

Concerning needs satisfaction across life domains, some pioneering studies suggest that the relation between needs satisfaction in the work and non-work domains may be compensatory. That is, employees benefit particularly from needs satisfaction in the nonwork domain if a need is not satisfied at work (Hewett et al., 2017). On the other hand, other studies have found that needs satisfaction during work and during leisure were positively related, both cross-sectionally (Walker \& Kono, 2018) and in diary studies (Van Hooff \& Geurts, 2015), suggesting spillover between life domains and pointing to gain or loss spirals across domains.

Our integrative model accounts for this by detailing how crafting motivations and crafting efforts are related across identity domains. We sought representational simplicity and 
depicted two identity domains simply as two distinct domains in Figure 1. However, our view of identity domains is episodic in nature (Beal, Weiss, Barros, \& MacDermid, 2005) with behaviors and experiences being linked across domains and complex dynamics unfolding over time.

Due to advances in technology and the changing nature of working life,the boundaries surrounding individuals' identity domains are rarely independent of one another, linking crafting motivation, efforts, and outcomes across identities. Due to limited research on the mechanisms that link multiple identity domains, we derive our theorization on the relationships among identity domains mainly from the literature on the relationship between the work and non-work domains as described in work-family research (e.g., Edwards \& Rothbard, 2000). Accordingly, we identify three linking mechanisms of compensation, spillover, and conflict (Edwards \& Rothbard, 2000) as shown in paths P10 and P11 in Figure 1. Given the centrality of a needs framework as the basis of human behavior, we excluded segmentation as a potential mechanism ${ }^{4}$.

Compensation refers to offsetting dissatisfaction in one domain by seeking satisfaction in another domain (Edwards \& Rothbard, 2000). As psychological needs and needs satisfaction are not specific to certain domains, we propose that employees' crafting is compensatory. Dissatisfied in her need for affiliation, a person will attempt approach-focused crafting in all identity domains. However, given limited opportunities for crafting in one identity domain, she will attempt a greater level of crafting in another domain. We assume that individuals can compensate for unmet needs in one domain by pursuing crafting targeted

\footnotetext{
${ }^{4}$ Early work-family researchers hypothesized that segmentation, defined as the separation of work and nonwork domains, may be possible and that behaviors, cognitions, and emotions in one life domain can, at least theoretically, be independent of behaviors, cognitions, and emotions in other life domains (e.g., Burke \& Greenglass, 1987; Zedeck, 1992). Empirical research has subsequently shown, however, that experiences within domains are usually closely related. Segmentation is now viewed as an active process of maintaining boundaries between life domains (Edwards \& Rothbard, 2000). Accordingly, we consider segmentation as a crafting effort at the interface of different identities.
} 
at these unmet needs in another domain. This corroborates Petrou's and Bakker's (2016) findings on job and leisure crafting suggesting that those with fewer opportunities to craft their job are more likely to compensate through leisure crafting. Accordingly, the compensatory mechanism is an important element the Integrative Needs Model of Crafting linking crafting efforts across identity domains.

Proposition 12: Crafting processes across identity domains are linked in a compensatory manner such that limited opportunities to craft in one identity domain result in higher motivation to craft in another identity domain.

Spillover refers to the similarities between constructs in one domain and related but distinct constructs in another (Edwards \& Rothbard, 2000). Applied to crafting, the spillover mechanism in our model suggests that crafting motives, actual crafting efforts, and outcomes are similar across identity domains. In other words, one domain may be seen as an extension of the other, leading to similar crafting motives, efforts, and outcomes in all domains. The conceptual implication is that dispositions and motivational tendencies may play an important role in crafting spillover. For instance, those more inclined to satisfying affiliation needs are more likely to engage in similar crafting efforts across identity domains targeting the satisfaction of the affiliation need (Chick \& Hood, 1996; Hofer \& Busch, 2011). Demerouti et al. (2019) recently found support for the spillover effect in crafting. Seeking resources at work and home, as well as seeking challenges there, was positively interrelated. Autonomy and workload at home strengthened these associations. Personality traits like proactivity may also predispose certain persons to engage more frequently than others in crafting efforts across different identity domains, leading to congruence in crafting efforts (e.g., Edwards \& Rothbard. 2000; McCormick et al., 2018; Parker, Williams, \& Turner, 2006). Similarly, identity research suggests that having multiple identities benefits and enhances well-being, because individuals have more behavioral repertoire at their disposal (Thoits, 1983; 1986). 
If, for instance, an employee crafts her work so as to feel more competent, she may feel more satisfied and happier about her work (proximal outcome). This feeling may, in turn, enhance her mood and interactions with her partner at home (distal outcome). This spillover assumption mirrors research on the work-family interface, which has shown associations between the satisfaction of needs in both work and family functioning (e.g., Kossek \& Ozeki, 1998; Tang et al., 2017).

Proposition 13: Crafting processes (i.e., motives, efforts and outcomes) across identity domains are linked through spillover mechanisms, such that positive and negative crafting experiences in one domain spill over into another domain.

The conflict mechanism, on the other hand, refers to the incompatibility of role demands, either imposed by others or self-imposed based on personal values (Edwards \& Rothbard, 2000). Applied to the crafting process, crafting efforts can be considered a selfimposed demand. Thus, the conflict mechanism suggests that investing time, attention, and energy in crafting efforts in one domain reduces an individual's resources for crafting in another domain. Thus, we propose:

Proposition 14: Crafting processes across identity domains are linked through the conflict mechanism, such that engaging in crafting in one identity domain results in lower engagement in crafting in another identity domain due to reduced availability of resources.

We propose that each mechanism (i.e., compensation, spillover conflict) may dominate in different phases of crafting. More specifically, we expect compensation to dominate the motivation stage, whereas conflict dominates the effort phase and spillover operates in all phases (i.e., motives, efforts, outcomes). While compensation and spillover may appear contradictory, compensation serves primarily to link life domains in the motivation stage. For example, compensating for one domain's unmet needs may suggest an emphasis on particular needs or motives for crafting in another domain. At this stage, 
compensation is most efficacious if an individual has little opportunity for crafting and needs satisfaction in one domain compared to another. On the other hand, an individual's disposition and motivational tendencies may result in spillover and similarities in the types of needs targeted across domains (i.e., motivation), in addition to similarities in crafting across domains. We expect conflict to operate mainly at the effort phase in the crafting process, meaning that a person's resources in terms of energy and time are limited. For instance, when a person attempts to boost feelings of competence by accomplishing more challenging tasks at work, she is less likely to engage in crafting efforts in leisure time due to depleted time and energy. Further, consistent with the spillover hypothesis, needs satisfaction and optimal functioning in one identity domain following crafting may spill over to other domains, resulting in similarities in domain-specific well-being (e.g., Amstad \& Semmer, 2009; Geurts \& Demerouti, 2003; Hecht \& Boies, 2009; Staines, 1980).

\section{Conceptual Advances, Limitations, and Avenues for Future Research}

The Integrative Needs Model of Crafting provides fruitful avenues for future research by identifying psychological needs as the motivation for crafting efforts, what constitutes crafting behaviors and cognitions, and what the outcomes of crafting are.

The use of non-domain-specific psychological needs as crafting motivators allows us to extend the crafting process across different life domains, including work, non-work, and the interface between the two. Below, we identify various areas for future research based on existing research and the tenets of the Integrative Needs Model of Crafting, organized into 1) crafting processes, 2) crafting across life domains, 3) crafting over time, and 4) individual and contextual considerations in crafting.

\section{Crafting Processes}

First, the Integrative Needs Model of Crafting provides an expanded conceptual basis to explore the crafting process (i.e., needs discrepancy, behavioral and cognitive crafting, 
needs satisfaction, and outcomes). By distinguishing between needs discrepancy and needs satisfaction and locating them in different phases of the crafting process, we integrate past theoretical frameworks of crafting and empirical research. The review of the literature in this light suggests that we know less about the motivating effects of needs discrepancy on crafting behaviors than about the needs satisfaction effects of these behaviors. Thus, more research is needed to establish the effects of needs discrepancy on crafting behaviors, especially with regard to avoidance needs, which lack a "grand theory" such as self-determination, which focuses on approach needs. Overall, our model can integrate various needs, but the question as to which exact needs should be integrated into the model remains an issue for future research. Given a clear distinction between the types of needs discrepancy (i.e., approach vs. avoidance needs) future research can also seek to understand how, why, and under what conditions different types of needs discrepancy predict different types of crafting behaviors (i.e., approach vs. avoidance crafting).

The Integrative Needs Model of Crafting also serves to reveal when crafting may not lead to optimal functioning by proposing a matching perspective between needs discrepancy and crafting behaviors. This explains why not all crafting is equally effective. While the results of some empirical studies support this notion (e.g., Petrou et al., 2012; Sheldon \& Niemiec, 2006), few studies have explicitly investigated this proposition. Future research is needed to better understand the match, when the mismatch would have the most negative effects (e.g., extremely unbalanced needs satisfaction), and the conditions under which the mismatch is most likely to occur.

Since crafting is an intentional, goal-directed process relying on deliberate attempts to increase needs satisfaction, our model, like the vast majority of the research on the relationships between needs and crafting, focuses on explicit needs discrepancy (e.g., Bindl et al., 2018). That is, according to our definition of crafting, individuals should be aware of their 
needs discrepancy before engaging in crafting efforts. However, this does not mean that possible implicit (i.e., unconcious) needs discrepancy cannot motivate individuals to craft. Overall, the question of the relationship between explicit and implicit motives remains largely unresolved (Sheldon, 2011), and how implicit motives relate to the crafting process requires further study (see also Ryan, Soenens. \& Vansteenkiste, 2019).

\section{Crafting and Life Domains}

Our integrative model explicates the mechanisms linking the crafting process across identity domains and at their interfaces. While past research has mainly focused on crafting at work, the increasing interest in and recognition of the importance of work and non-work interface within organizational research has directed more research toward a holistic understanding of organizational phenomena - including crafting. Taking an identity perspective, we propose that individuals may engage in distinct crafting efforts within different identity domains and that research should examine a more extensive set of non-work identities as well as taking a more meticulous approach to a multitude of work identities. Our conceptual model can serve as a theoretical framework for future research to examine the crafting process from an identity perspective.

From a broader cross-domain perspective, this integrative review suggests that our understanding of crafting efforts outside the work domain and their influence on well-being and functioning at work is limited and more research is needed to achieve a more holistic view of the why and how of crafting. The Integrative Needs Model of Crafting identifies needs independent of a specific life domain as the underlying motivation for crafting that can be used to explore what motivates crafting outside the work context and its outcomes. The literature on non-work crafting and crafting at the interfaces of life domains has likewise focused mainly on leisure crafting. While leisure is an important aspect of people's lives, the non-work domain encompasses other roles and identities that should also be considered as 
potentially amenable to crafting (Kuykendall et al., 2017). For instance, how workers adjust their family-related responsibilities, relationships, and activities to their needs and enhance their functioning at and outside work is a crucial but little researched aspect. Grounded in non-domain-specific psychological needs, the model can be applied to broader non-work roles, identities, and domains to provide a holistic view of crafting and its functions.

The literature on non-work crafting can also be expanded by distinguishing between different types of crafting efforts. While the job crafting literature takes a detailed approach to various forms of crafting behaviors (e.g., task, relational, and cognitive crafting, demandresource crafting, and prevention-promotion crafting), no distinction has been made in nonwork crafting research between the different types of crafting. The Integrative Needs Model of Crafting relies on a broad categorization of approach-avoidance crafting that is also applicable to crafting outside the work context. Future research can further our understanding of crafting by identifying and operationalizing crafting efforts that individuals employ in nonwork domains and how these efforts affect needs satisfaction and well-being at work and outside work.

In addition, the model can further help account for how crafting motivation and actual crafting efforts within and across identity domains are interrelated and influence one another. Well-being may peak if needs are all satisfied and in balance (Sheldon \& Niemiec, 2006) and reach its lowest levels if certain needs are entirely unmet and/or if social contexts cause conflicts between needs (Ryan \& Deci, 2000). An interesting aspect of the new model is the question of whether certain needs may be stronger drivers within a certain life domain. For instance, the need for competence may be a stronger driver for crafting one's job rather than crafting one's role as a parent, whereas the need for relatedness may be a stronger driver outside the work context. Our tentative proposition is that optimal functioning requires 
balance in satisfaction of different needs within and between domains (Sheldon \& Niemiec, 2006).

The Integrative Needs Model of Crafting can also be applied to closely related fields, such as psychological detachment (i.e., abstaining from job-related activities and mentally disengaging from work during leisure time; Sonnentag \& Fritz, 2015), to broaden the scope of theoretical and empirical investigation. For example, the literature on psychological detachment suggests that psychological detachment both mediates and moderates in the relationship between job stressors and optimal functioning (Sonnentag \& Fritz, 2015). That is, while psychological detachment is impaired by job stressors, resulting in strain and illbeing (Sonnentag \& Bayer, 2005), it can also buffer the negative effect of job stressors on individual well-being (Sonnentag, Binnewies, \& Mojza, 2010). The literature so far has typically treated psychological detachment as a passive experience that "happens" to people and is disrupted by work stressors. However, this process should also be understood from a crafting perspective; that is, individuals may proactively shape their work and non-work activities in order to detach from their work (or non-work) roles, satisfy their needs, and achieve optimal functioning (for an intervention using daily planning behavior to actively facilitate detachment, see Smit \& Barber, 2016). Similarly, other recovery experiences may often be the result of a person's proactive attempts to satisfy specific needs, rather than experiential events that "simply happen". Since recovery is positively associated with employee well-being and performance (Steed, Swider, Keem, \& Liu, 2019), proactive attempts to achieve better recovery through needs satisfaction may provide an important avenue for organizational research and practices. This process may be particularly useful for recovery experiences associated with gaining new internal resources and engagement in relatively effortful activities such as exercise or volunteer work (e.g., Feuerhahn, Sonnentag, \& Woll, 2014; Mojza, Sonnentag, \& Bornemann, 2011; Nägel, Sonnentag, \& Kühnel, 2015). 


\section{Crafting Over Time}

The Integrative Needs Model of Crafting can also explain how crafting experiences change or impact future crafting. The crucial role of time in organizational research has been increasingly recognized and there is a burgeoning interest in integrating time into the theory and measurement of various organizational phenomena (Eldor et al., 2017; Ford et al., 2014; Mitchell \& James, 2001; Shipp \& Cole, 2015; Sonnentag, 2012;). Specifically, within-person changes in constructs (i.e., changes in variables within the context of time rather than because of time; Shipp \& Cole, 2015) is an important aspect for integration into organizational theories. Within the crafting context, while there are some longitudinal and lagged studies examining antecedents and/or outcomes of job crafting (e.g., Harju, Hakanen, \& Schaufeli, 2016; Tims, Bakker, \& Derks, 2015; Vogt, Hakanen, Brauchli, Jenny, \& Bauer, 2016), these studies do not examine how past crafting experiences influence future crafting efforts.

Future research, adopting longitudinal and within-person designs, will be required to examine the temporal dynamics of crafting processes. This is especially important because the positive link between needs discrepancy and needs satisfaction may cancel out when examined concurrently because needs both initiate crafting behaviors and lead to needs satisfaction, and needs satisfaction diminishes people's motivation to craft. Accordingly, these links can only be fully understood when time is taken into consideration. Experimental research and ecological momentary assessments of participants' motives as well as (simulating) needs satisfaction may be one way to examine the feedback loop (i.e., comparing desired states to actual states to reduce discrepancies; Lord et al., 2010) between needs discrepancy, crafting efforts, and needs satisfaction. Such research could yield important insights on the onset, offset, duration, and dynamic development of crafting processes across different time frames and on the importance of motives and needs (dis)satisfaction for initiating and continuing crafting. Measurement issues are also an important consideration in 
this regard. We echo Zhang and Parkers' (2018) call to develop measures for the new types of crafting identified, focusing on the relevant identity context. In addition, research on the crafting process should examine levels of avoidance or approach needs (e.g., "need strength" as assessed in Chen et al., 2015) as well as needs satisfaction. This would enable researchers to identify needs discrepancy and potential (mis)match between individuals' needs and crafting efforts.

\section{Individual and Contextual Considerations in Crafting}

Our Integrative Needs Model of Crafting provides a more extensive understanding of contextual factors. Crafting may be affected not only by variables in the immediate work and non-work domains but also by variables in the cultural context surroundings work and nonwork as described in earlier sections. Due to space limitations, we are not able to develop indepth theoretical arguments about different types of moderators. Overall, we believe that the most important contextual factors are those promoting (or preventing) the autonomysupportive context as these factors facilitate (or impede) perseverance and performance to satisfy psychological needs (Deci \& Ryan, 2008; Sheldon \& Elliot, 1999; Vansteenkiste et al., 2004). Even though our model focuses on individual-level processes, contextual variables and organizational factors (e.g., organizational climate, supervisor and co-worker support, spousal support) are very important, with a major impact onindividual employees' abilities to engage in crafting efforts. We consider crafting an activity requiring support from the wider environment in order to be effective (i.e., work, non-work). Future research can also further elucidate which and how these individual and contextual factors might operate differently across domains.

Crafting has mostly been investigated so far among highly educated knowledge and service workers (Rudolph et al., 2017). While it has been suggested that any job can be crafted, research in support of this claim is scarce. Studies with broader samples including 
less educated employees with considerably lower levels of autonomy would serve to demonatrate whether crafting is indeed independent of social class and education.

Limited research has examined the role of volatile contextual factors on the crafting process. For instance, we know very little about how a particular event (e.g., promotion, having a child) affects the crafting motivation and the strength of the relationship between motivation and actual crafting efforts. Similarly, we know little about how objective (who, what, when, where, and which; Johns, 2006) and subjective situational characteristics (CAPTION model; Parrigon, Woo, Tay, \& Wang, 2017) influence the crafting process. Future research focusing on these aspects could reveal more about the crafting process and its boundary conditions. Overall, the explanatory power of needs as drivers for behavior and needs satisfaction and the precursors of well-being is limited. Earlier research showed that variance in optimal functioning explained by needs satisfaction varies between 10 and 54 percent (Tay \& Diener, 2011; Van den Broeck, Ferris, Chang, \& Rosen, 2016). This leaves a significant share to be explained by factors such as positive and negative affect, monetary rewards or non-work life characteristics such as family constraints or conflicts.

\section{Practical implications}

The proposed Integrative Needs Model of Crafting can also serve as a framework to guide individual and organizational practices. By identifying potential mismatches between individual needs and crafting efforts, interventions can be tailored to address unsatisfied needs, enabling individuals to make more need-sensitive choices in their crafting efforts. People may habitually target needs already satisfied, leading to unbalanced need profiles. Interventions could help people to become more aware of their unsatisfied needs and target 
their crafting attempts at the satisfaction of these specific needs (see also Sheldon \& Niemiec, 2006).

Considering the importance and increasingly interwoven nature of employees' work and non-work domains (e.g., Brough \& O’Driscoll, 2010; Tetrick \& Winslow, 2015), organizational interventions stimulating crafting in various life domains seem a very promising tool for promoting optimal functioning. Particularly when introduced as part of wider occupational wellness programs and other organizational policies aimed at reconciling work and non-work domains, individual-level crafting at work and outside work may perfectly complement organizational interventions, thereby making them more effective (Lamontagne, Keegel, Louie, Ostry, \& Landsbergis, 2007; Petrou, Demerouti, \& Schaufeli, 2018).

\section{Conclusions}

Seeking to advance and accumulate knowledge on crafting entails integrating different crafting life perspectives and identities. Our integrative conceptual review integrates the crafting literature (i.e., job, non-work, and interface crafting) into a common framework. Our Integrative Needs Model of Crafting distinguishes and integrates crafting motivation (i.e., needs discrepancy), actual crafting efforts, and needs satisfaction, which explains why people engage in crafting and predicts how they will craft across different identity domains. Our holistic approach to crafting views humans as active agents proactively seeking to maximize need fulfillment within structural considerations and across multiple identities in various life domains. It also stresses the importance of the work and the non-work context for enabling or impeding crafting and illustrates why job crafting may not fully compensate for poorly designed jobs or highly stressful family life. Synthesizing the literature on crafting, psychological needs, work- and non-work identities will create synergies between hitherto unconnected lines of research and pave the way for new lines of inquiry. 


\section{References}

Allen, T. D., Cho, E., \& Meier, L. L. (2014). Work-family boundary dynamics. Annual Review of Organizational Psychology and Organizational Behavior, 1(1), 99-121.

Amstad, F. T., Meier, L. L., Fasel, U., Elfering, A., \& Semmer, N. K. (2011). A metaanalysis of work-family conflict and various outcomes with a special emphasis on cross-domain versus matching-domain relations. Journal of Occupational Health Psychology, 16(2), 151-169.

Amstad, F. T., \& Semmer, N. K. (2009). Recovery and the work-family interface. In P. Perrewé, J. Halbesleben, \& C. Rose (Eds.), Current perspectives on job-stress recovery (pp. 125-166). Bingley: Emerald Group Publishing Limited.

Ashforth, B. E. (2001). Role transitions in organizational life. An identity-based perspective. Mahwah, NJ: Lawrence Erlbaum Associates.

Ashforth, B. E., Kreiner, G. E., Fugate, M. (2000). All in a day's work: Boundaries and micro role transitions. Academy of Management Review, 25, 472-491.

Ashforth, B. E., Schinoff, B. S., \& Rogers, K. M. 2016. "I identify with her," "I identify with him": Unpacking the dynamics of personal identification in organizations. Academy of Management Review, 41(1), 28-60

Atkinson, J. W. (1992). Motivational determinants of thematic apperception. In A. J. Stewart (Ed.), Motivation and society (pp. 3-40). New York, NY, US: Cambridge University Press.

Bakker, A. B., \& Demerouti, E. (2017). Job demands-resources theory: Taking stock and looking forward. Journal of Occupational Health Psychology, 22(3), 273-285.

Beal, D. J., Weiss, H. M., Barros, E., \& MacDermid, S. M. (2005). An episodic process model of affective influences on performance. Journal of Applied Psychology, 90(6), $1054-1068$. 
Behson, S. J. (2002). Coping with family-to-work conflict: the role of informal work accommodations to family. Journal of Occupational Health Psychology, 7(4), 324-341.

Berdicchia, D., \& Masino, G. (2017). Exploring the antecedents of job crafting: A conditional process analysis. International Journal of Business and Management, 12(12), 1-14.

Berg, J. M., Dutton, J. E., \& Wrzesniewski, A. (2013). Job crafting and meaningful work. In B. J. Dik, Z. S. Byrne \& M. F. Steger (Eds.), Purpose and meaning in the workplace (pp. 81-104). Washington, DC: American Psychological Association.

Berg, J. M., Grant, A. M., \& Johnson, V. (2010). When callings are calling: Crafting work and leisure in pursuit of unanswered occupational callings. Organization Science, 21(5), 973--994.

Berg, J. M., Wrzesniewski, A., \& Dutton, J. E. (2010). Perceiving and responding to challenges in job crafting at different ranks: When proactivity requires adaptivity. Journal of Organizational Behavior, 31(2-3), 158-186.

Berger, L. J., Essers, C., \& Himi, A. (2017). Muslim employees within "white" organizations: The case of Moroccan workers in the Netherlands. The International Journal of Human Resource Management, 28(8), 1119-1139.

Bindl, U. K., Unsworth, K., Gibson, C. B., \& Stride, C. B. (2018). Job crafting revisited: Implications of an extended framework for active changes at work. Journal of Applied Psychology. Advance online publication.

Blader, S. L., \& Tyler, T. R. (2009). Testing and extending the group engagement model: Linkages between social identity, procedural justice, economic outcomes, and extra-role behavior. Journal of Applied Psychology, 94(2), 445-464.

Blasche, G., Pasalic, S., Bauböck, V.-M., Haluza, D., \& Schoberberger, R. (2017). Effects of rest-break intention on rest-break frequency and work-related fatigue. Human Factors, 59(2), 289-298. 
Bogaerts, Y., De Cooman, R. D., \& De Gieter, S. D. (2018). Getting the work-nonwork interface you are looking for: The relevance of work-nonwork boundary management fit. Frontiers in Psychology. Advance online publication.

Brough, P., \& O'Driscoll, M. P. (2010). Organizational interventions for balancing work and home demands: An overview. Work \& Stress, 24(3), 280-297.

Bruning, P. F., \& Campion, M. A. (2018). A role-resource approach-avoidance model of job crafting: A multimethod integration and extension of job crafting theory. Academy of Management Journal, 61(2), 499-522.

Bulger, C. A., Matthews, R. A., \& Hoffman, M. E. (2007). Work and personal life boundary management: Boundary strength, work/personal life balance, and the segmentationintegration continuum. Journal of Occupational Health Psychology, 12(4), 365-375.

Burke, P. J. (2003). Relationships among multiple identities. In Advances in identity theory and research (pp. 195-214). Boston, MA: Springer.

Burke, P. J. (2006). Identity Change. Social Psychology Quarterly, 69(1), 81-96.

Burke, R. J., \& Greenglass, E. (1987). Work and family. In C. L. Cooper \& I. T. Robertson (Eds.), International review of industrial and organizational psychology (pp. 273320). New York, NY: Wiley.

Burke, P. J., \& Reitzes, D. C. (1981). The link between identity and role performance. Social Psychology Quarterly, 44(2), 83-92.

Cable, D. M., Gino, F., \& Staats, B. R. (2013). Breaking them in or eliciting their best? Reframing socialization around newcomers' authentic self-expression. Administrative Science Quarterly, 58(1), 1-36.

Carver, C. S., \& Scheier, M. F. (1981). Attention and self-regulation: A control theory approach to human behavior. New York, NY: Springer-Verlag. 
Caza, B. B., Vough, H., \& Puranik, H. (2018). Identity work in organizations and occupations: Definitions, theories, and pathways forward. Journal of Organizational Behavior, 39(7), 889-910.

Chen, B., Vansteenkiste, M., Beyers, W., Boone, L., Deci, E. L., Van der Kaap-Deeder, J., . . . Verstuyf, J. (2015). Basic psychological need satisfaction, need frustration, and need strength across four cultures. Motivation and Emotion, 39(2), 216-236.

Chen, Y.-P., Shaffer, M., Westman, M., Chen, S., Lazarova, M., \& Reiche, S. (2014). Family role performance: Scale development and validation. Applied Psychology, 63(1), 190 218.

Chick, G., \& Hood, R. D. (1996). Working and recreating with machines: Outdoor recreation choices among machine-tool employees in western Pennsylvania. Leisure Sciences, 18(4), 333-354.

Clair, J. A., Beatty, J. E., \& MacLean, T. L. (2005). Out of sight but not out of mind: Managing invisible social identities in the workplace. Academy of Management Review, 30(1), 78-95.

Clark, S. C. (2000). Work/family border theory: A new theory of work/family balance. Human Relations, 53(6), 747-770.

Conroy, S. A., Becker, W. J., \& Menges, J. I. (2017). The meaning of my feelings depends on who I am: Work-related identifications shape emotion effects in organizations. Academy of Management Journal, 60(3), 1071-1093.

Creed, W. D., DeJordy, R., \& Lok, J. (2010). Being the change: Resolving institutional contradiction through identity work. Academy of Management Journal, 53(6), 13361364. 
Czekierda, K., Banik, A., Park, C. L., \& Luszczynska, A. (2017). Meaning in life and physical health: Systematic review and meta-analysis. Health Psychology Review, 11(4), 387-418.

De Jonge, J., \& Dormann, C. (2003). The DISC Model: demand induced strain compensation mechanisms in job stress. In: M. F. Dollard, A. H. Winefield, H. R. Winefield (Eds.), Occupational stress in the service professions (pp. 43-74). London, UK: Taylor \& Francis.

De Jonge, J., \& Dormann, C. (2006). Stressors, resources, and strain at work: A longitudinal test of the triple-match principle. Journal of Applied Psychology, 91, 1359-1374.

De Jonge, J., Dormann, C., \& Van den Tooren, M. (2008). The demand-induced strain compensation model: renewed theoretical considerations and empirical evidence. In K. Näswall, J. Hellgren, \& M. Sverke (Eds.): The individual in the changing working life (pp. 67-87). Cambridge: Cambridge University Press.

Deci, E. L., Olafsen, A. H., \& Ryan, R. M. (2017). Self-determination theory in work organizations: the state of a science. Annual Review of Organizational Psychology and Organizational Behavior, 4, 19-43.

Deci, E. L., \& Ryan, R. M. (2008). Self-determination theory: A macro-theory of human motivation, development and health. Canadian Psychology, 49(3), 182-185.

Demerouti, E., Bakker, A. B., \& Gevers, J. M. P. (2015). Job crafting and extra-role behavior: The role of work engagement and flourishing. Journal of Vocational Behavior, 91, 87-96.

Demerouti, E., Hewett, R., Haun, V., De Gieter, S., Rodríguez-Sánchez, A., \& Skakon, J. (2019). From job crafting to home crafting: A daily diary study among six European countries. Human Relations. 
Demerouti, E., \& Peeters, M. C. W. (2018). Transmission of reduction-oriented crafting among colleagues: A diary study on the moderating role of working conditions. Journal of Occupational and Organizational Psychology, 91(2), 209-234.

Dierdorff, E. C., \& Jensen, J. M. (2018). Crafting in context: Exploring when job crafting is dysfunctional for performance effectiveness. Journal of Applied Psychology, 103(5), 463-477.

Edwards, J. R., \& Rothbard, N. P. (2000). Mechanisms linking work and family: Clarifying the relationship between work and family constructs. Academy of Management Review, 25(1), 178-199.

Eldor, L., Fried, Y., Westman, M., Levi, A. S., Shipp, A. J., \& Slowik, L. H. (2017). The experience of work stress and the context of time. Organizational Psychology Review, $7(3), 227-249$.

Ellemers, N., \& Rink, F. (2005). Identity in work groups: The beneficial and detrimental consequences of multiple identities and group norms for collaboration and group performance. In Social identification in groups (pp. 1-41). Emerald Group Publishing Limited.

Elliot, A. J. (2006). The hierarchical model of approach-avoidance motivation. Motivation and emotion, 30(2), 111-116.

Essers, C., Doorewaard, H., \& Benschop, Y. (2013). Family ties: Migrant female business owners doing identity work on the public-private divide. Human Relations, 66(12), $1645-1665$.

Feuerhahn, N., Sonnentag, S., \& Woll, A. (2014). Exercise after work, psychological mediators, and affect: A day-level study. European Journal of Work and Organizational Psychology, 23(1), 62-79. 
Ford, M. T., Matthews, R. A., Wooldridge, J. D., Mishra, V., Kakar, U. M., \& Strahan, S. R. (2014). How do occupational stressor-strain effects vary with time? A review and meta-analysis of the relevance of time lags in longitudinal studies. Work \& Stress, 28(1), 9-30.

Fritz, C., Lam, C. F., \& Spreitzer, G. M. (2011). It's the little things that matter: An examination of knowledge employees' energy management. The Academy of Management Perspectives, 25(3), 28-39.

Gagnon, S. (2008). Compelling identity: Selves and insecurity in global, corporate management development. Management Learning, 39(4), 375-391.

Gelfand, M. J., Nishii, L. H., \& Raver, J. L. (2006). On the nature and importance of cultural tightness-looseness. Journal of Applied Psychology, 91(6), 1225-1244.

Geurts, S. A., \& Demerouti, E. (2003). Work/non-work interface: A review of theories and findings. In M. J. Schambracq, Winnubst, J. A. M., Cooper, C. L. (Eds.), The handbook of work and health psychology (Vol. 2, pp. 279-312). West Sussex, UK: Wiley.

Gibson, C. B., Maznevski, M. L., \& Kirkman, B. L. (2009). When does culture matter? In R. S. Bhagat \& R. M. Steers (Eds.), Cambridge handbook of culture, organizations, and work (pp. 46-68). New York, NY: Cambridge University Press.

Gordon, H. J., Demerouti, E., Le Blanc, P. M., \& Bipp, T. (2015). Job crafting and performance of Dutch and American health care professionals. Journal of Personnel Psychology, 14(4), 192-202.

Grant, A. M., \& Parker, S. K. (2009). Redesigning work design theories: The rise of relational and proactive perspectives. Academy of Management Annals, 3(1), 317375. 
Gravador, L. N., \& Teng-Calleja, M. (2018). Work-life balance crafting behaviors: An empirical study. Personnel Review, 47(4), 786-804.

Green, P. I., Finkel, E. J., Fitzsimons, G. M., \& Gino, F. (2017). The energizing nature of work engagement: Toward a new need-based theory of work motivation. Research in Organizational Behavior, 37, 1-18.

Greenhaus, J. H., \& Beutell, N. J. (1985). Sources of conflict between work and family roles. Academy of Management Review, 10(1), 76-88.

Halbesleben, J. R. B., Neveu, J.-P., Paustian-Underdahl, S. C., \& Westman, M. (2014). Getting to the "COR": Understanding the role of resources in conservation of resources theory. Journal of Management, 40(5), 1334-1364.

Harju, L. K., Hakanen, J. J., \& Schaufeli, W. B. (2016). Can job crafting reduce job boredom and increase work engagement? A three-year cross-lagged panel study. Journal of Vocational Behavior, 95, 11-20.

Hecht, T. D., \& Boies, K. (2009). Structure and correlates of spillover from nonwork to work: An examination of nonwork activities, well-being, and work outcomes. Journal of Occupational Health Psychology, 14(4), 414-426.

Hewett, R., Haun, V. C., Demerouti, E., Rodríguez Sánchez, A. M., Skakon, J., \& De Gieter, S. (2017). Compensating need satisfaction across life boundaries: A daily diary study. Journal of Occupational and Organizational Psychology, 90(2), 270-279.

Higgins, E. T. (1998). Promotion and prevention: Regulatory focus as a motivational principle. In M. P. Zanna (Ed.), Advances in experimental social psychology (Vol. 30, pp. 1-46). Academic Press.

Hofer, J., \& Busch, H. (2011). Satisfying one's needs for competence and relatedness: Consequent domain-specific well-being depends on strength of implicit motives. Personality and Social Psychology Bulletin, 37(9), 1147-1158. 
Hull, C. L. (1943). Principles of behavior: An introduction to behavior theory. New York, NY: Appleton-Century-Crofts.

Hülsheger, U. R. (2016). From dawn till dusk: Shedding light on the recovery process by investigating daily change patterns in fatigue. Journal of Applied Psychology, 101(6), 905-914.

Ibarra, H., \& Barbulescu, R. (2010). Identity as narrative: Prevalence, effectiveness, and consequences of narrative identity work in macro work role transitions. Academy of management review, 35(1), 135-154.

Iwasaki, Y. (2007). Leisure and quality of life in an international and multicultural context: What are major pathways linking leisure to quality of life? Social Indicators Research, 82(2), 233-264.

Johns, G. (2006). The essential impact of context on organizational behavior. Academy of management review, 31(2), 386-408

Johnson, R. E., Chang, C. H., Meyer, T., Lanaj, K., \& Way, J. (2013). Approaching success or avoiding failure? Approach and avoidance motives in the work domain. European Journal of Personality, 27(5), 424-441.

Kim, G.-N., \& Lee, Y.-M. (2016). Towards high performance organization: The impacts of job characteristics and job crafting. International Journal of $U$-and e-Service, Science and Technology, 9(2), 85-100.

Kooij, D. T. A. M., Van Woerkom, M., Wilkenloh, J., Dorenbosch, L., \& Denissen, J. J. A. (2017). Job crafting towards strengths and interests: The effects of a job crafting intervention on person-job fit and the role of age. Journal of Applied Psychology, 102(6), 971-981. 
Kossek, E. E., Lautsch, B. A., \& Eaton, S. C. (2006). Telecommuting, control, and boundary management: Correlates of policy use and practice, job control, and work-family effectiveness. Journal of Vocational Behavior, 68(2), 347-367.

Kossek, E., \& Ozeki, C. (1998). Work-family conflict, policies, and the job-life satisfaction relationship: A review and directions for organizational behavior-human resources research. Journal of Applied Psychology, 83(2), 139-149.

Kossek, E. E., Ruderman, M. N., Braddy, P. W., \& Hannum, K. M. (2012). Work-nonwork boundary management profiles: A person-centered approach. Journal of Vocational Behavior, 81(1), 112-128.

Kreiner, G. E., Hollensbe, E. C., \& Sheep, M. L. (2009). Balancing borders and bridges: Negotiating the work-home interface via boundary work tactics. Academy of Management Journal, 52, 704-730.

Kreiner, G. E., Hollensbe, E. C., \& Sheep, M. L. (2006). Where is the "me" among the "we"? Identity work and the search for optimal balance. Academy of Management Journal, 49(5), 1031-1057.

Kühnel, J., Vahle-Hinz, T., De Bloom, J., \& Syrek, C. J. (2017). Staying in touch while at work: Relationships between personal social media use at work and work-nonwork balance and creativity. International Journal of Human Resource Management. Advance online publication.

Kuykendall, L., Lei, X., Tay, L., Cheung, H. K., Kolze, M., Lindsey, A., . . . Engelsted, L. (2017). Subjective quality of leisure \& employee well-being: Validating measures \& testing theory. Journal of Vocational Behavior, 103, 14-40.

Ladge, J. J., Clair, J. A., \& Greenberg, D. (2012). Cross-domain identity transition during liminal periods: Constructing multiple selves as professional and mother during pregnancy. Academy of Management Journal, 55(6), 1449-1471. 
Lamontagne, A. D., Keegel, T., Louie, A. M., Ostry, A., \& Landsbergis, P. A. (2007). A systematic review of the job-stress intervention evaluation literature, 1990-2005. International Journal of Occupational and Environmental Health, 13(3), 268-280.

Lapierre, L. M., Van Steenbergen, E. F., Peeters, M. C., \& Kluwer, E. S. (2016). Juggling work and family responsibilities when involuntarily working more from home: A multiwave study of financial sales professionals. Journal of Organizational Behavior, $37(6), 804-822$.

Lazazzara, A., Tims, M., \& de Gennaro, D. (2019). The process of reinventing a job: A meta-synthesis of qualitative job crafting research. Journal of Vocational Behavior. Advance online publication.

Lichtenthaler, P. W., \& Fischbach, A. (2018). A meta-analysis on promotion- and preventionfocused job crafting. European Journal of Work and Organizational Psychology, $28(1), 30-50$.

Lin, B., Law, K. S., \& Zhou, J. (2017). Why is underemployment related to creativity and OCB? A task-crafting explanation of the curvilinear moderated relations. Academy of Management Journal, 60(1), 156-177.

Little, L. M., Major, V. S., Hinojosa, A. S., \& Nelson, D. L. (2015). Professional image maintenance: How women navigate pregnancy in the workplace. Academy of Management Journal, 58(1), 8-37.

Lord, R. G., Diefendorff, J. M., Schmidt, A. M., \& Hall, R. J. (2010). Self-regulation at work. Annual Review of Psychology, 61(1), 543-568.

Lu, C. Q., Wang, H. J., Lu, J. J., Du, D. Y., \& Bakker, A. B. (2014). Does work engagement increase person-job fit? The role of job crafting and job insecurity. Journal of Vocational Behavior, 84(2), 142-152. 
Lyons, P. (2008). The crafting of jobs and individual differences. Journal of Business and Psychology, 23(1), 25-36.

Mäkikangas, A. (2018). Job crafting profiles and work engagement: A person-centered approach. Journal of Vocational Behavior, 106, 101-111.

Martela, F., \& Riekki, T. J. J. (2018). Autonomy, competence, relatedness, and beneficence: A multicultural comparison of the four pathways to meaningful work. Frontiers in Psychology. Advance online publication.

Maslow, A. H. (1943). A theory of human motivation. Psychological Review, 50(4), 370396.

McClelland, D. (1985). Human motivation. Glenview, IL: Scott, Foresman.

McCormick, B. W., Guay, R. P., Colbert, A. E., \& Stewart, G. L. (2018). Proactive personality and proactive behaviour: Perspectives on person-situation interactions. Journal of Occupational and Organizational Psychology.

McDowall, A., \& Lindsay, A. (2014). Work-life balance in the police: The development of a self-management competency framework. Journal of Business and Psychology, 29(3), $397-411$.

Milyavskaya, M., \& Koestner, R. (2011). Psychological needs, motivation, and well-being: A test of self-determination theory across multiple domains. Personality and Individual Differences, 50(3), 387-391.

Miller, G. A., Galanter, E., \& Pribram, K. H. (1960). Plans and the structure of behavior. New York, NY: Henry Holt and Co.

Mitchell, T. R., \& James, L. R. (2001). Building better theory: Time and the specification of when things happen. Academy of Management Review, 26(4), 530-547.

Mojza, E. J., Sonnentag, S., \& Bornemann, C. (2011). Volunteer work as a valuable leisuretime activity: A day-level study on volunteer work, non-work experiences, and well- 
being at work. Journal of Occupational and Organizational Psychology, 84(1), 123152.

Murray, H. A. (1938). Explorations in personality: A clinical and experimental study of fifty men of college age. New York, NY: Oxford University Press.

Nägel, I. J., Sonnentag, S., \& Kühnel, J. (2015). Motives matter: A diary study on the relationship between job stressors and exercise after work. International Journal of Stress Management, 22(4), 346-371.

Newman, D. B., Tay, L., \& Diener, E. (2014). Leisure and subjective well-being: A model of psychological mechanisms as mediating factors. Journal of Happiness Studies, 15, $555-578$.

Nielsen, K., \& Abildgaard, J. S. (2012). The development and validation of a job crafting measure for use with blue-collar employees. Work \& Stress, 26(4), 365-384.

Nielsen, K., Antino, M., Sanz-Vergel, A., \& Rodriguez-Munoz, A. (2017). Validating the Job Crafting Questionnaire (JCRQ): A multi-method and multi-sample study. Work \& Stress, 31(1), 82-99.

Niessen, C., Weseler, D., \& Kostova, P. (2016). When and why do individuals craft their jobs? The role of individual motivation and work characteristics for job. Human Relations, 69(6), 1287-1313.

Obodaru, O. (2017). Forgone, but not forgotten: Toward a theory of forgone professional identities. Academy of Management Journal, 60(2), 523-553.

Oldham, G. R., \& Fried, Y. (2016). Job design research and theory: Past, present and future. Organizational Behavior and Human Decision Processes, 136, 20-35.

Op den Kamp, E. M., Bakker, A. B., Tims, M., \& Demerouti, E. (2018b). Proactive vitality management and creative work performance: The Role of Self-Insight and Social Support. The Journal of Creative Behavior. 
Op den Kamp, E. M., Tims, M., Bakker, A. B., \& Demerouti, E. (2018a). Proactive vitality management in the work context: development and validation of a new instrument. European Journal of Work and Organizational Psychology, 27(4), 493-505.

Parrigon, S., Woo, S. E., Tay, L., \& Wang, T. (2017). CAPTION-ing the situation: A lexically-derived taxonomy of psychological situation characteristics. Journal of Personality and Social Psychology, 112(4), 642-681.

Parker, S. K., Bindl, U. K., \& Strauss, K. (2010). Making things happen: A model of proactive motivation. Journal of Management, 36(4), 827-856.

Parker, S. K., Morgeson, F. P., \& Johns, G. (2017). One hundred years of work design research: Looking back and looking forward. Journal of Applied Psychology, 102(3), $403-420$.

Parker, S. K., Williams, H. M., \& Turner, N. (2006). Modeling the antecedents of proactive behavior at work. Journal of Applied Psychology, 91(3), 636-652.

Peterson, M. F., \& Barreto, T. S. (2014). The like it or not proposition: Implications of societal characteristics for the cultural expertise and personal values of organization members. Journal of Organizational Behavior, 35(8), 1134-1152.

Peterson, M. F., \& Wood, R. (2008). Cognitive structures and processes in cross-cultural management. In P. B. Smith, M. F. Peterson, \& D. C. Thomas (Eds.), The handbook of cross-cultural management research (pp. 15-34). Thousand Oaks, CA: Sage.

Petrou, P., \& Bakker, A. B. (2016). Crafting one's leisure time in response to high job strain. Human Relations, 69(2), 507-529.

Petrou, P., Bakker, A. B., \& Van den Heuvel, M. (2017). Weekly job crafting and leisure crafting: Implications for meaning-making and work engagement. Journal of Occupational and Organizational Psychology, 90(2), 129-152. 
Petrou, P., Demerouti, E., Peeters, M. C. W., Schaufeli, W. B., \& Hetland, J. (2012). Crafting a job on a daily basis: Contextual correlates and the link to work engagement. Journal of Organizational Behavior, 33(8), 1120-1141.

Petrou, P., Demerouti, E., \& Schaufeli, W. (2018). Crafting the change: The role of employee job crafting behaviors for successful organizational change. Journal of Management, 44(5), 1766-1792.

Pratt, M. G., Rockmann, K. W., \& Kaufmann, J. B. (2006). Constructing professional identity: The role of work and identity learning cycles in the customization of identity among medical residents. Academy of Management Journal, 49(2), 235-262.

Radel, R., Pelletier, L. G., Sarrazin, P., \& Milyavskaya, M. (2011). Restoration process of the need for autonomy: The early alarm stage. Journal of Personality and Social Psychology, 101(5), 919-934.

Radstaak, M., \& Hennes, A. (2017). Leader-member exchange fosters work engagement: The mediating role of job crafting. SA Journal of Industrial Psychology, 43(1), 1-11.

Ramarajan, L. (2014). Past, present and future research on multiple identities: Toward an intrapersonal network approach. Academy of Management Annals, 8(1), 589-659.

Riketta, M. (2005). Organizational identification: A meta-analysis. Journal of Vocational Behavior, 66(2), 358-384

Rofcanin, Y., Bakker, A. B., Berber, A., Gölgeci, I., \& Las Heras, M. (2018). Relational job crafting: Exploring the role of employee motives with a weekly diary study. Human Relations, 0018726718779121.

Rosa, H. (2013). Social acceleration: A new theory of modernity. New York, NY: Columbia University Press. 
Rudolph, C. W., Katz, I. M., Lavigne, K. N., \& Zacher, H. (2017). Job crafting: A metaanalysis of relationships with individual differences, job characteristics, and work outcomes. Journal of Vocational Behavior, 102, 112-138.

Ryan, R. M., Bernstein, J. H., \& Brown, K. W. (2010). Weekends, work, and well-being: Psychological need satisfactions and day of the week effects on mood, vitality, and physical symptoms. Journal of Social and Clinical Psychology, 29(1), 95-122.

Ryan, R. M., \& Deci, E. L. (2000). Self-Determination Theory and the facilitation of intrinsic motivation, social development, and well-being. American Psychologist, 55, 68-78.

Ryan, R. M., Soenens, B., \& Vansteenkiste, M. (2019). Reflections on self-determination theory as an organizing framework for personality psychology: Interfaces, integrations, issues, and unfinished business. Journal of Personality, 87(1), 115-145.

Ryff, C. D. and C. L. M. Keyes (1995). The structure of psychological well-being revisited. Journal of Personality and Social Psychology 69(4), 719-727.

Salancik, G. R., \& Pfeffer, J. (1978). A social information processing approach to job attitudes and task design. Administrative Science Quarterly, 224-253.

Schüler, J., Brandstätter, V., \& Sheldon, K. M. (2013). Do implicit motives and basic psychological needs interact to predict well-being and flow? Testing a universal hypothesis and a matching hypothesis. Motivation and Emotion, 37(3), 480-495.

Schüler, J., Job, V., Fröhlich, S. M., \& Brandstätter, V. (2008). A high implicit affiliation motive does not always make you happy: A corresponding explicit motive and corresponding behavior are further needed. Motivation and Emotion, 32(3), 231-242.

Shaw, S. M. (1985). The meaning of leisure in everyday life. Leisure sciences, 7(1), 1-24.

Sheldon, K. M. (2011). Integrating behavioral-motive and experiential-requirement perspectives on psychological needs: A two-process model. Psychological Review, $118(4), 552-569$. 
Sheldon, K. M., Abad, N., \& Hinsch, C. (2011). A two-process view of Facebook use and relatedness need-satisfaction: Disconnection drives use, and connection rewards it. Psychology of Popular Media Culture, 1(S), 2-15.

Sheldon, K. M., \& Cooper, M. L. (2008). Goal striving within agentic and communal roles: Separate but functionally similar pathways to enhanced well-being. Journal of Personality, 76(3), 415-448.

Sheldon, K. M., \& Elliot, A. J. (1999). Goal striving, need satisfaction, and longitudinal wellbeing: The self-concordance model. Journal of Personality and Social Psychology, $76(3), 482-497$.

Sheldon, K. M., Elliot, A. J., Kim, Y., \& Kasser, T. (2001). What is satisfying about satisfying events? Testing 10 candidate psychological needs. Journal of Personality and Social Psychology, 80(2), 325-339.

Sheldon, K. M., \& Niemiec, C. P. (2006). It's not just the amount that counts: Balanced need satisfaction also affects well-being. Journal of Personality and Social Psychology, 91(2), 331-341.

Sheldon, K. M., \& Schüler, J. (2011). Wanting, having, and needing: Integrating motive disposition theory and self-determination theory. Journal of Personality and Social Psychology, 101(5), 1106-1123.

Shipp, A. J., \& Cole, M. S. (2015). Time in individual-level organizational studies: What is it, how is it used, and why isn't it exploited more often? Annual Review of Organizational Psychology and Organizational Behavior, 2(1), 237-260.

Shipp, A. J., \& Jansen, K. J. (2011). Reinterpreting time in fit theory: Crafting and recrafting narratives of fit in medias res. Academy of Management Review, 36(1), 76-101.

Shockley, K. M., \& Singla, N. (2011). Reconsidering work-family interactions and satisfaction: A meta-analysis. Journal of Management, 37(3), 861-886. 
Slemp, G. R., \& Vella-Brodrick, D. A. (2014). Optimising employee mental health: The relationship between intrinsic need satisfaction, job crafting, and employee wellbeing. Journal of Happiness Studies, 15(4), 957-977.

Sluss, D. M., Ployhart, R. E., Cobb, M. G., \& Ashforth, B. E. (2012). Generalizing newcomers' relational and organizational identifications: Processes and prototypicality. Academy of Management Journal, 55(4). 949-975.

Smit, B. W., \& Barber, L. K. (2016). Psychologically detaching despite high workloads: The role of attentional processes. Journal of Occupational Health Psychology, 21(4), 432442.

Snow, D. A., \& Anderson, L. (1987). Identity work among the homeless: The verbal construction and avowal of personal identities. American Journal of Sociology, 92(6), $1336-1371$.

Soenens, B., \& Vansteenkiste, M. (2010). A theoretical upgrade of the concept of parental psychological control: Proposing new insights on the basis of self-determination theory. Developmental Review, 30, 74-99.

Sonnentag, S. (2012). Time in organizational research: Catching up on a long-neglected topic in order to improve theory. Organizational Psychology Review, 2(4), 361-368.

Sonnentag, S., \& Bayer, U. V. (2005). Switching off mentally: Predictors and consequences of psychological detachment from work during off-job time. Journal of Occupational Health Psychology, 10(4), 393-414.

Sonnentag, S., Binnewies, C., \& Mojza, E. J. (2010). Staying well and engaged when demands are high: The role of psychological detachment. Journal of Applied Psychology, 95(5), 965-976. 
Sonnentag, S., \& Fritz, C. (2007). The recovery experience questionnaire: Development and validation of a measure for assessing recuperation and unwinding from work. Journal of Occupational Health Psychology, 12, 204-221.

Sonnentag, S., \& Fritz, C. (2015). Recovery from job stress: The stressor-detachment model as an integrative framework. Journal of Organizational Behavior, 36(1), 72-103.

Sonnentag, S., Venz, L., \& Casper, A. (2017). Advances in recovery research: What have we learned? What should be done next? Journal of Occupational Health Psychology, 22(3), 365-380.

Staines, G. L. (1980). Spillover versus compensation: A review of the literature on the relationship between work and non-work. Human Relations, 33(2), 111-129.

Steed, L. B., Swider, B. W., Keem, S., \& Liu, J. T. (2019). Leaving work at work: A metaanalysis on employee recovery from work. Journal of Management. Advance online publication.

Steidle, A., Gonzalez-Morales, M. G., Hoppe, A., Michel, A., \& O’Shea, D. (2017).

Energizing respites from work: a randomized controlled study on respite interventions. European Journal of Work and Organizational Psychology, 26(5), 650662.

Stryker, S., \& Burke, P. J. (2000). The past, present, and future of an identity theory. Social Psychology Quarterly, 284-297.

Stryker, S., \& Serpe, R. T. (1994). Identity salience and psychological centrality: Equivalent, overlapping, or complementary concepts? Social Psychology Quarterly, 16-35.

Sturges, J. (2012). Crafting a balance between work and home. Human Relations, 65(12), $1539-1559$.

Tay, L., \& Diener, E. (2011). Needs and subjective well-being around the world. Journal of Personality and Social Psychology, 101(2), 354-365. 
Ten Brummelhuis, L. L., \& Trougakos, J. P. (2014). The recovery potential of intrinsically versus extrinsically motivated off-job activities. Journal of Occupational and Organizational Psychology, 87(1), 177-199.

Tetrick, L. E., \& Winslow, C. J. (2015). Workplace stress management interventions and health promotion. Annual Review of Organizational Psychology and Organizational Behavior, 2(1), 583-603.

Thøgersen-Ntoumani, C., Ntoumanis, N., \& Nikitaras, N. (2010). Unhealthy weight control behaviours in adolescent girls: A process model based on self-determination theory. Psychology \& Health, 25, 535-550.

Thoits, P. A. (1986). Multiple identities: Examining gender and marital status differences in distress. American Sociological Review, 259-272.

Thoits, P. A. (1983). Multiple identities and psychological well-being: A reformulation and test of the social isolation hypothesis. American Sociological Review, 174-187.

Thrane, C. (2000). Men, women, and leisure time: Scandinavian evidence of gender inequality. Leisure Sciences, 22(2), 109-122.

Tims, M., \& Bakker, A. B. (2010). Job crafting: Towards a new model of individual job redesign. South African Journal of Industrial Psychology, 36(2), 1-9.

Tims, M., Bakker, A. B., \& Derks, D. (2012). Development and validation of the job crafting scale. Journal of Vocational Behavior, 80(1), 173-186.

Tims, M., Bakker, A. B., \& Derks, D. (2013). The impact of job crafting on job demands, job resources, and well-being. Journal of Occupational Health Psychology, 18(2), 230240.

Tims, M., Bakker, A. B., \& Derks, D. (2015). Examining job crafting from an interpersonal perspective: Is employee job crafting related to the wellbeing of colleagues? Applied Psychology, 64(4), 727-753. 
Tims, M., Derks, D., \& Bakker, A. B. (2016). Job crafting and its relationships with personjob fit and meaningfulness: A three-wave study. Journal of Vocational Behavior, 92, $44-53$.

Tinsley, H. E. A., \& Eldredge, B. D. (1995). Psychological benefits of leisure participation: A taxonomy of leisure activities based on their need-gratifying properties. Journal of Counseling Psychology, 42(2), 123-132.

Tooby, J., \& Cosmides, L. (1990). On the universality of human nature and the uniqueness of the individual: The role of genetics and adaptation. Journal of personality, 58(1), 1767.

Ullrich, J., Wieseke, J., Christ, O., Schulze, M., \& Van Dick, R. (2007). The identitymatching principle: Corporate and organizational identification in a franchising system. British Journal of Management, 18, 29-S44.

Uz, I. (2015). The Index of cultural tightness and looseness among 68 countries. Journal of Cross-Cultural Psychology, 46(3), 319-335.

Van den Broeck, A., Ferris, Chang, \& Rosen (2016). A review of self-determination theory's basic psychological needs at work. Journal of Management, 42(5), 1195-1229.

Van Hooff, M. L., \& Geurts, S. A. (2015). Need satisfaction and employees' recovery state at work: A daily diary study. Journal of Occupational Health Psychology, 20(3), 377-387. Vansteenkiste, M., \& Ryan, R. M. (2013). On psychological growth and vulnerability: Basic psychological need satisfaction and need frustration as a unifying principle. Journal of Psychotherapy Integration, 23(3), 263-280.

Vansteenkiste, M., Simons, J., Lens, W., Sheldon, K. M., \& Deci, E. L. (2004). Motivating learning, performance, and persistence: The synergistic effects of intrinsic goal contents and autonomy-supportive contexts. Journal of Personality and Social Psychology, 87(2), 246-260. 
Van Wingerden, J., Bakker, A. B., \& Derks, D. (2017a). Fostering employee well-being via a job crafting intervention. Journal of Vocational Behavior, 100, 164-174.

Van Wingerden, J., Derks, D., \& Bakker, A. B. (2017b). The impact of personal resources and job crafting interventions on work engagement and performance. Human Resource Management, 56(1), 51-67.

Vanbelle, E., Van den Broeck, A., \& De Witte, H. (2013). Development and validation of a general job crafting scale. Manuscript under review

Vancouver, J. B. (2000). Self-regulation in organizational settings: A tale of two paradigms. In Vohs, K. D., \& Baumeister, R. F. (Eds.). Handbook of self-regulation: Research, theory and applications. New York, NY: Guildford Publications.

Vancouver, J. B., Thompson, C. M., \& Williams, A. A. (2001). The changing signs in the relationships among self-efficacy, personal goals, and performance. Journal of Applied Psychology, 86(4), 605-620.

Vaziri, H. (2018). Me, Myself, and I, at Work and at Home, Today, Tomorrow, and the Day After. In Academy of Management Proceedings (Vol. 2018, No. 1). Briarcliff Manor, NY: Academy of Management.

Vignoles, V., Regalia, C., Manzi, C., Golledge, J., \& Scabini, E. 2006. Beyond self-esteem: influence of multiple motives on identity construction. Journal of Personality and Social Psychology, 90(2), 308-33.

Vogel, R. M., Rodell, J. B., \& Lynch, J. W. (2016). Engaged and productive misfits: How job crafting and leisure activity mitigate the negative effects of value incongruence. Academy of Management Journal, 59(5), 1561-1584.

Vogt, K., Hakanen, J. J., Brauchli, R., Jenny, G. J., \& Bauer, G. F. (2016). The consequences of job crafting: A three-wave study. European Journal of Work and Organizational Psychology, 25(3), 353-362. 
Vroom, V. H. (1964). Work and motivation. New York, NY: Wiley.

Walker, G. J., \& Kono, S. (2018). The effects of basic psychological need satisfaction during leisure and paid work on global life satisfaction. Journal of Positive Psychology, 13(1), 36-47.

Wang, H. J., Demerouti, E., \& Le Blanc, P. (2017). Transformational leadership, adaptability, and job crafting: The moderating role of organizational identification. Journal of Vocational Behavior, 100, 185-195.

Wessels, C., Schippers, M. C., Stegmann, S., Bakker, A. B., van Baalen, P. J., \& Proper, K. I. (2019). Fostering flexibility in the new world of work: A model of time-spatial job crafting. Frontiers in Psychology, 10(505).

Wrzesniewski, A., \& Dutton, J. E. (2001). Crafting a job: Revisioning employees as active crafters of their work. Academy of Management Review, 26(2), 179-201.

Yepes-Baldó, M., Romeo, M., Westerberg, K., \& Nordin, M. (2018). Job crafting, employee well-being, and quality of care. Western Journal of Nursing Research, 40(1), 52-66.

Zacher, H., Brailsford, H. A., \& Parker, S. L. (2014). Micro-breaks matter: A diary study on the effects of energy management strategies on occupational well-being. Journal of Vocational Behavior, 85(3), 287-297.

Zedeck, S. (1992). Work, families, and organizations. San Francisco, CA: Jossey-Bass

Zhang, F., \& Parker, S. K. (2018). Reorienting job crafting research: A hierarchical structure of job crafting concepts and integrative review. Journal of Organizational Behavior. 
Table 1: Integration of different crafting models using the Integrative Needs Model of Crafting

\begin{tabular}{|c|c|c|c|c|}
\hline Conceptual model & Crafting motives & Crafting behaviors and cognitions & Domain & Outcomes investigated \\
\hline $\begin{array}{l}\text { Job crafting } \\
\text { (Wrzesniewski \& Dutton, 2001) }\end{array}$ & $\begin{array}{l}\text { Needs satisfaction } \\
\text { (i.e., control, positive self- } \\
\text { image, human connection) }\end{array}$ & $\begin{array}{l}\text { Avoidance-focused (task strategies), Approach- } \\
\text { focused (task-, relational-, cognitive strategies) }\end{array}$ & Work & $\begin{array}{l}\text { (b) WR well-being/performance } \\
\text { (meanings, positive work identity) }\end{array}$ \\
\hline $\begin{array}{l}\text { Job crafting } \\
\text { (Tims \& Bakker, 2010; } \\
\text { Vanbelle, Van den Broeck, \& } \\
\text { De Witte, 2013) }\end{array}$ & $\begin{array}{l}\text { Needs discrepancy } \\
\text { (i.e., perceived person-job } \\
\text { (mis)fit; motivation to } \\
\text { optimize functioning) }\end{array}$ & $\begin{array}{l}\text { Avoidance-focused (lowering hindering } \\
\text { demands), Approach-focused (increasing } \\
\text { challenging demands, social and structural } \\
\text { resources) }\end{array}$ & Work & $\begin{array}{l}\text { (a) Needs satisfaction (e.g., } \\
\text { meaning) } \\
\text { (b) WR well-being/performance } \\
\text { (e.g., work engagement, job } \\
\text { performance, job satisfaction) } \\
\text { (c) SWB/ family role performance } \\
\text { (e.g., resilience, thriving) }\end{array}$ \\
\hline $\begin{array}{l}\text { Approach-avoidance crafting } \\
\text { (Bruning \& Campion, 2018) }\end{array}$ & - & $\begin{array}{l}\text { Avoidance-focused (structural crafting: role } \\
\text { reduction, withdrawal), Approach-focused } \\
\text { (structural crafting: role expansion, adoption of } \\
\text { knowledge and technology; structural crafting: } \\
\text { work organization; social crafting: social } \\
\text { expansion; cognitive crafting: metacognition) }\end{array}$ & Work & $\begin{array}{l}\text { (b) WR well-being/performance } \\
\text { (e.g., job enrichment, engagement, } \\
\text { reduced strain, job performance) }\end{array}$ \\
\hline $\begin{array}{l}\text { Crafting towards strengths and } \\
\text { interests } \\
\text { (Kooij, Van Woerkom, } \\
\text { Wilkenloh, Dorenbosch, \& } \\
\text { Denissen, 2017) }\end{array}$ & $\begin{array}{l}\text { Needs discrepancy } \\
\text { (i.e., perceived fit between } \\
\text { job, personal strengths and } \\
\text { interests) }\end{array}$ & $\begin{array}{l}\text { Approach-focused (interests and strengths } \\
\text { crafting) }\end{array}$ & Work & $\begin{array}{l}\text { (b) WR well-being/performance } \\
\text { (e.g., demands-abilities fit, needs- } \\
\text { supplies fit) }\end{array}$ \\
\hline $\begin{array}{l}\text { Extended framework of job } \\
\text { crafting } \\
\text { (Bindl et al., 2018) }\end{array}$ & $\begin{array}{l}\text { Needs discrepancy } \\
\text { (i.e., need for relatedness, } \\
\text { competence, and } \\
\text { autonomy) }\end{array}$ & $\begin{array}{l}\text { Avoidance-focused (task, skill, relational, } \\
\text { cognitive), Approach-focused (task, skill, } \\
\text { relational, cognitive) }\end{array}$ & Work & $\begin{array}{l}\text { (b) WR well-being/performance } \\
\text { (e.g., innovative work } \\
\text { performance) }\end{array}$ \\
\hline $\begin{array}{l}\text { Leisure crafting } \\
\text { (Berg, Grant, et al., 2010) }\end{array}$ & $\begin{array}{l}\text { Needs discrepancy } \\
\text { (i.e., unfulfilled callings at } \\
\text { work) }\end{array}$ & $\begin{array}{l}\text { Approach-focused (vicariously experiencing and } \\
\text { hobby participation) }\end{array}$ & $\begin{array}{l}\text { Non- } \\
\text { work }\end{array}$ & $\begin{array}{l}\text { (c) SWB/ family role performance } \\
\text { (e.g., hedonic- and eudaimonic } \\
\text { well-being) }\end{array}$ \\
\hline $\begin{array}{l}\text { Leisure crafting } \\
\text { (Petrou \& Bakker, 2016; Petrou } \\
\text { et al., 2017) }\end{array}$ & $\begin{array}{l}\text { Needs satisfaction } \\
\text { (i.e., human connection, } \\
\text { goal-setting, learning, } \\
\text { personal development) }\end{array}$ & $\begin{array}{l}\text { Approach-focused (task-, and relational } \\
\text { strategies) }\end{array}$ & $\begin{array}{l}\text { Non- } \\
\text { work }\end{array}$ & $\begin{array}{l}\text { (a) Needs satisfaction (e.g., } \\
\text { meaning, competence, } \\
\text { relatedness) }\end{array}$ \\
\hline
\end{tabular}




\begin{tabular}{|c|c|c|c|c|}
\hline Conceptual model & Crafting motives & Crafting behaviors and cognitions & Domain & Outcomes investigated \\
\hline $\begin{array}{l}\text { Home crafting } \\
\text { (Demerouti et al., 2019) }\end{array}$ & $\begin{array}{l}\text { Needs discrepancy } \\
\text { (i.e., perceived (mis)fit) }\end{array}$ & $\begin{array}{l}\text { Avoidance-focused (reducing demands), } \\
\text { Approach-focused (seeking resources, seeking } \\
\text { challenges) }\end{array}$ & $\begin{array}{l}\text { Non- } \\
\text { work }\end{array}$ & 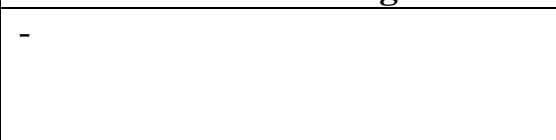 \\
\hline $\begin{array}{l}\text { Work-life balance crafting } \\
\text { (Behson, 2002; Sturges, 2012; } \\
\text { Gravador \& Teng-Calleja, 2018) }\end{array}$ & $\begin{array}{l}\text { Needs discrepancy } \\
\text { (i.e., preferred balance } \\
\text { between work and non- } \\
\text { work) }\end{array}$ & $\begin{array}{l}\text { Avoidance-focused (physical crafting, protecting } \\
\text { free time, limiting work demands), Promotion- } \\
\text { focused (relational-, cognitive crafting, fostering } \\
\text { relationships, work-related strategies) }\end{array}$ & Interface & $\begin{array}{l}\text { (c) SWB/ family role performance } \\
\text { (e.g., work-life balance, subjective } \\
\text { well-being) }\end{array}$ \\
\hline $\begin{array}{l}\text { Boundary management, } \\
\text { segmentation strategies, micro } \\
\text { role transitions } \\
\text { (Ashforth et al., 2000; Bogaerts } \\
\text { et al., 2018, Bulger et al., 2007; } \\
\text { McDowall, \& Lindsay, 2014) }\end{array}$ & $\begin{array}{l}\text { Needs discrepancy } \\
\text { (i.e., preference for } \\
\text { segmentation or integration } \\
\text { of life domains; work- } \\
\text { /non-work boundary } \\
\text { management fit) }\end{array}$ & $\begin{array}{l}\text { Avoidance-focused (rites of separation, keeping } \\
\text { perspective, prioritizing, expectation } \\
\text { management), Approach-focused (rites of } \\
\text { incorporation, cooperation and coordination) }\end{array}$ & Interface & $\begin{array}{l}\text { (b) WR well-being/performance } \\
\text { (e.g., task variety, job satisfaction, } \\
\text { organizational commitment, } \\
\text { turnover intention, occupational } \\
\text { stress) } \\
\text { (c) SWB/ family role perf (e.g., } \\
\text { role identification, work-life } \\
\text { conflict, work-life balance) }\end{array}$ \\
\hline $\begin{array}{l}\text { Energy/vitality management } \\
\text { (Blasche, Pasalic, Bauböck, } \\
\text { Haluza, \& Schoberberger, 2017; } \\
\text { Fritz, Lam, \& Spreitzer, 2011; } \\
\text { Op den Kamp, Tims, Bakker, \& } \\
\text { Demerouti, 2018a) }\end{array}$ & $\begin{array}{l}\text { Needs satisfaction } \\
\text { (i.e., energy conservation } \\
\text { and replenishment) }\end{array}$ & $\begin{array}{l}\text { Avoidance-focused (non-work related strategies, } \\
\text { rest breaks) Approach-focused (non-work related } \\
\text { and work-related strategies) }\end{array}$ & Work & $\begin{array}{l}\text { (b) WR well-being/performance } \\
\text { (e.g., vitality, reduced fatigue, } \\
\text { reduced distress, effort } \\
\text { motivation) }\end{array}$ \\
\hline
\end{tabular}

Notes: SWB=subjective well-being. WR=work-related. 
Table 2: Different types of needs and examples of accompanying crafting efforts across different identities (work, non-work \& interface)

\begin{tabular}{|c|c|c|c|c|}
\hline \multicolumn{2}{|c|}{ Examples for needs } & $\begin{array}{l}\text { Crafting efforts within a work } \\
\text { identity }\end{array}$ & $\begin{array}{l}\text { Crafting efforts at the interface } \\
\text { of identities }\end{array}$ & $\begin{array}{l}\text { Crafting efforts within a nonwork } \\
\text { identity }\end{array}$ \\
\hline \multirow{3}{*}{ 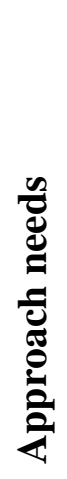 } & Autonomy & $\begin{array}{l}\text { Take charge of a new project at } \\
\text { work (supervisor) }\end{array}$ & $\begin{array}{l}\text { Change work location to adjust to } \\
\text { family demands (employee, parent) }\end{array}$ & $\begin{array}{l}\text { Take charge of an event at church } \\
\text { (Christian) }\end{array}$ \\
\hline & Competence & $\begin{array}{l}\text { Learn a new computer program } \\
\text { (programmer) }\end{array}$ & $\begin{array}{l}\text { Take on new work responsibilities } \\
\text { during pregnancy (pregnant mother, } \\
\text { employee) }\end{array}$ & $\begin{array}{l}\text { Take a language course to integrate } \\
\text { into a new home country (immigrant) }\end{array}$ \\
\hline & Relatedness & $\begin{array}{l}\text { Establish new collaborations with } \\
\text { colleagues abroad (researcher) }\end{array}$ & $\begin{array}{l}\text { Organize an after-work get together } \\
\text { with colleagues (co-worker, friend) }\end{array}$ & Arrange regular date nights (spouse) \\
\hline \multirow{3}{*}{ 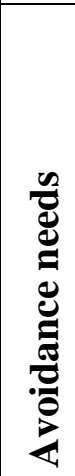 } & Detachment & $\begin{array}{l}\text { Engage in regular mindfulness } \\
\text { exercise at work (employee) }\end{array}$ & $\begin{array}{l}\text { Not responding to work emails at } \\
\text { home (employee, family member) }\end{array}$ & $\begin{array}{l}\text { Schedule periodic "me time" to } \\
\text { detach from parental role (parent) }\end{array}$ \\
\hline & Relaxation & $\begin{array}{l}\text { Engage in a routine, less } \\
\text { demanding task (employee) }\end{array}$ & $\begin{array}{l}\text { Pray during stressful times at work } \\
\text { (employee, Christian) }\end{array}$ & $\begin{array}{l}\text { Take regular sweat baths (sauna } \\
\text { lover) }\end{array}$ \\
\hline & Stress reduction & $\begin{array}{l}\text { Schedule fewer/shorter meetings } \\
\text { with colleagues to avoid getting } \\
\text { overwhelmed (co-worker) }\end{array}$ & $\begin{array}{l}\text { Establish clear boundaries between } \\
\text { work and family (employee, family } \\
\text { member) }\end{array}$ & $\begin{array}{l}\text { Reduce the workload of a voluntary } \\
\text { position in a charity organization } \\
\text { (volunteer) }\end{array}$ \\
\hline
\end{tabular}


Table 3. Illustrative studies examining different phases of the crafting process

\begin{tabular}{|c|c|c|c|}
\hline Relationships & Work & Interface & Non-work \\
\hline $\begin{array}{l}\text { Psychological Needs } \\
\rightarrow \text { Crafting Efforts }\end{array}$ & $\begin{array}{l}\text { - } \quad \text { Task-, Relational-, and Cognitive Job Crafting } \\
\text { o Need for positive self-image (Niessen et al., 2016)* } \\
\text { o Need for relatedness when self-efficacy is high (Niessen } \\
\text { et al., 2016)* } \\
\text { - } \quad \text { Optimizing/Reducing Demands } \\
\text { o Workload or work pressure as avoidance need (Demerouti } \\
\text { \& Peeters, 2018; Petrou et al., 2012) } \\
\text { - Approach and Avoidance Job Crafting } \\
\text { o Needs for autonomy, relatedness, and competence (Bindl } \\
\text { et al., 2018)* } \\
\text { - Selective cognitive processing } \\
\text { ○ Maintaining autonomy (Essers, Doorewaard, \& Benschop, } \\
\text { 2013) } \\
\text { Discursive tactics in constructing identity } \\
\text { ○ Display affiliation (Gagnon, 2008) }\end{array}$ & $\begin{array}{l}\text { - Time-spatial job crafting } \\
\text { O Boundary management styles, } \\
\text { individual needs \& attitudes (Wessels } \\
\text { et al., 2019) } \\
\text { - Job and Leisure crafting } \\
\text { o Unfulfilled values linked to forgone } \\
\text { professional identities (Obodaru, 2017) } \\
\text { - Identity change } \\
\text { O Meanings consistent (isomorphic) with } \\
\text { identity (Burke \& Reitzes, 1981) } \\
\text { Cognitive and behavioral identity work } \\
\text { O Maintaining self-consistency (Berger, } \\
\text { Essers, \& Himi, 2017; Creed, DeJordy, } \\
\text { \& Lok, 2010) } \\
\text { ○ Signal competence and } \\
\text { professionalism (Berger et al., 2017) }\end{array}$ & $\begin{array}{l}\text { - Leisure Crafting } \\
\text { ○ Job demands (i.e., } \\
\text { avoidance need) when } \\
\text { job autonomy was low } \\
\text { (Petrou \& Bakker, 2016) } \\
\text { - Home crafting } \\
\text { Home autonomy } \\
\text { strengthened the positive } \\
\text { association between job } \\
\text { crafting and home crafting } \\
\text { (Demerouti et al. 2019) }\end{array}$ \\
\hline $\begin{array}{l}\text { Crafting Efforts } \rightarrow \\
\text { Needs satisfaction }\end{array}$ & $\begin{array}{l}\text { Meaning } \\
\text { ○ Increasing structural resources, but not social resources or } \\
\text { challenging demands (Petrou, et al., 2017): } \\
\text { ○ Composite of demands/resource crafting (Tims et al., } \\
\text { 2016)* } \\
\text { o Approach relational crafting (Bruning \& Campion, 2018) } \\
\text { Intrinsic Needs satisfaction } \\
\text { ○ Task-, relational-, and cognitive job crafting (Slemp \& } \\
\text { Vella-Brodrick, 2014) } \\
\text { ○ Job crafting intervention that increased challenging job } \\
\text { demands crafting (Van Wingerden et al., 2017a)* } \\
\text { Needs-Supply Fit } \\
\circ \text { Approach relational job crafting (Lu et al., 2014) } \\
\circ \text { Composite of demands/resource crafting (Tims et al., } \\
\text { 2016)* } \\
\text { o Interest and strength job crafting (Kooij et al., 2017) }\end{array}$ & $--^{\mathrm{a}}$ & $\begin{array}{l}\text { Meaning } \\
\circ \text { Weekly Leisure Crafting } \\
\text { (Petrou et al., 2017) } \\
\text { Relatedness and Autonomy } \\
\circ \text { Weekly Leisure Crafting } \\
\text { (Petrou \& Bakker, 2016) }\end{array}$ \\
\hline $\begin{array}{l}\text { Crafting Efforts } \rightarrow \\
\text { Optimal functioning }\end{array}$ & $\begin{array}{l}\text { - Job Satisfaction and Engagement } \\
\text { ○ Increasing resources and decreasing demands (Dierdorff } \\
\text { \& Jensen, 2018; Nielsen et al., 2017) }\end{array}$ & $\begin{array}{l}\text { - Job Satisfaction and Engagement } \\
\text { O Informal work accommodations to } \\
\text { family (Behson, 2002) }\end{array}$ & $\begin{array}{l}\text { - Job Satisfaction and } \\
\text { Engagement }\end{array}$ \\
\hline
\end{tabular}




\begin{tabular}{|c|c|c|c|}
\hline & 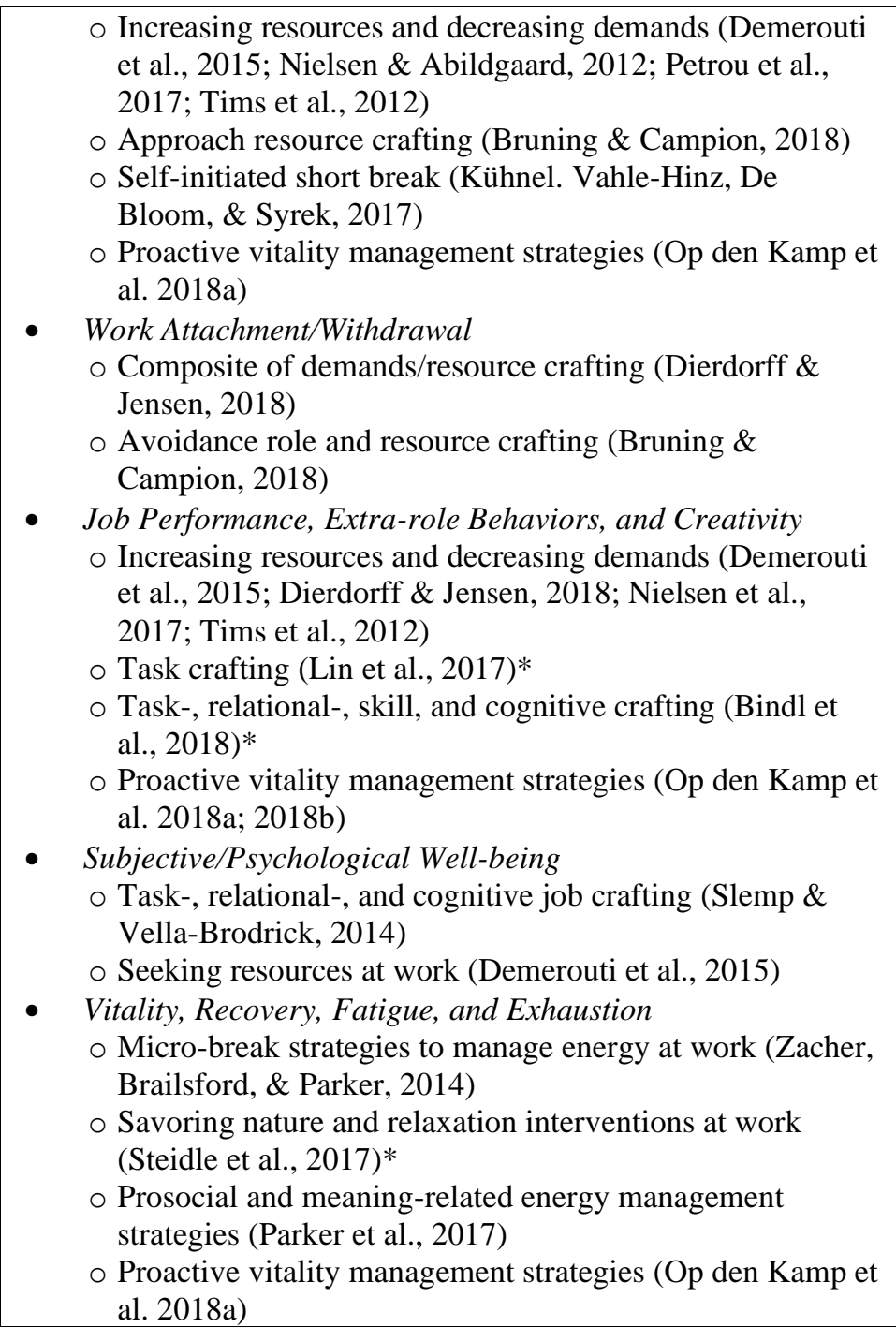 & $\begin{array}{l}\text { ○ Authentically expressing personal } \\
\text { identities at work (Cable, Gino, Staats, } \\
\text { 2013) } \\
\text { Job Performance and Creativity } \\
\circ \text { Time-spatial crafting (Wessels et al., } \\
\text { 2019) } \\
\circ \text { Informal work accommodations to } \\
\text { family (Behson, 2002) } \\
\text { Work-life Balance or Conflict } \\
\circ \text { Boundary crafting behaviors } \\
\text { (protecting private time, working } \\
\text { efficiently, and fostering relationship } \\
\text { with family; Gravador \& Teng- } \\
\text { Calleja, 2018) } \\
\circ \text { Work-family integration strategies } \\
\text { (Kossek, Lautsch, \& Eaton, 2006; } \\
\text { Lapierre, Van Steenbergen, Peeters, \& } \\
\text { Kluwer, 2016) } \\
\text { ○oundary work tactics (behavioral, } \\
\text { temporal, physical, and } \\
\text { communicative; Kreiner et al., 2009) } \\
\circ \text { Informal work accommodations to } \\
\text { family (Behson, 2002) } \\
\text { Subjective/Psychological Well-being } \\
\circ \text { Boundary crafting behaviors } \\
\text { (protecting private time and fostering } \\
\text { relationship with family; Gravador \& } \\
\text { Teng-Calleja, 2018) }\end{array}$ & $\begin{array}{l}\text { ○ Proactive leisure } \\
\text { activities (Vogel, } \\
\text { Rodell, \& Lynch, } \\
\text { 2016)* } \\
\text { Vitality, Recovery, Fatigue, } \\
\text { and Exhaustion } \\
\circ \text { Intrinsically motivated } \\
\text { leisure activities (Ten } \\
\text { Brummelhuis \& } \\
\text { Trougakos, 2014)* }\end{array}$ \\
\hline
\end{tabular}

Note: $\rightarrow=$ influences. $*=$ longitudinal study with time lag between variables. ${ }^{\text {a }}$ We are not aware of any empirical study examining the role of crafting at the interface on needs satisfaction. 


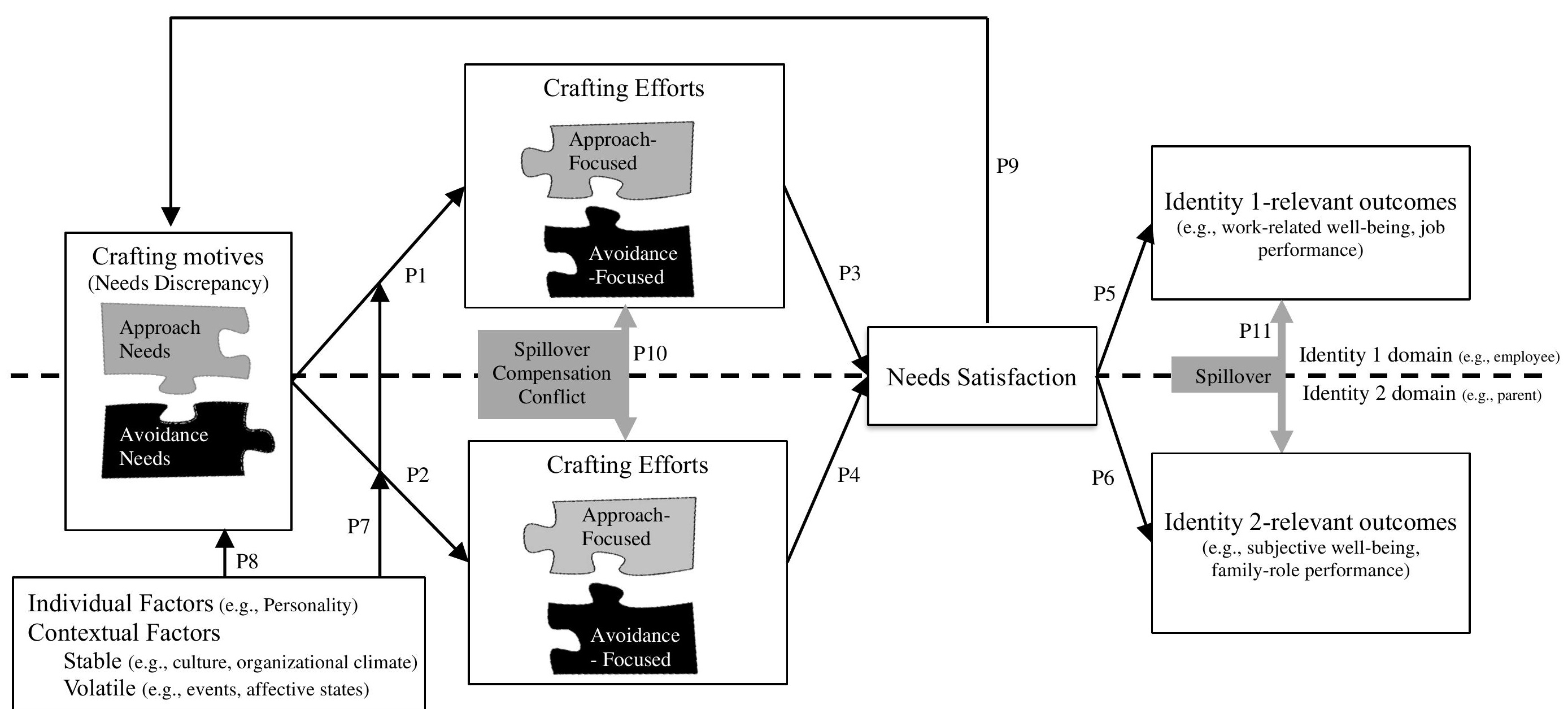

Figure 1. Integrative Needs Model of Crafting 